\title{
The Financial Crisis, Labor Market Transitions and Earnings: A Gendered Panel Data Analysis for Serbia ${ }^{\dagger}$
}

\author{
Niels-Hugo Blunch \\ Washington and Lee University \& IZA \\ blunchn@wlu.edu \\ Victor Sulla \\ The World Bank \\ vsulla@worldbank.org
}

This Version: May 25, 2011

JEL Classifications: I310, J2, J240, J6

Keywords: Financial crisis, gender, labor market flows, transition probabilities, earnings growth, panel data, Serbia

\begin{abstract}
While results are starting to emerge, not much is known yet about the dynamics of the labor markets of the former Eastern economies, especially in the context of the current Financial Crisis. Arguably, this is mainly due to paucity of (panel) data. By examining labor market transitions, earnings levels, and earnings growth and their correlates using a recent panel data set for Serbia, this paper combines both of these issues. Estimation of gross transition probabilities reveals that females are disadvantaged in the Serbian labor market in terms of moving out of the two undesirable states, unemployment and economic inactivity, relative to males during the first year of the financial crisis-though males are harder hit than females in terms of the levels of unemployment. In terms of earnings, the pictures is reversed, with females being worse off in terms of the levels of earnings, while they have experienced somewhat smaller earnings decreases than males (though, owing to the gender earnings gap, from a much lower base). Multinomial logit estimations of employment, unemployment, and inactivity transitions and OLS regressions of earnings and earnings growth reveal substantial gender differences related to individual, job, and firm characteristics. The overall results therefore hint at both males and females being hit in terms of employment and earnings, though in different ways. Finally, the paper discusses policy implications and provides suggestions for further research.
\end{abstract}

\footnotetext{
${ }^{\dagger}$ We thank Alicia Adsera, Hank Farber, David Lee, seminar participants at Princeton University (Industrial Relations Section Graduate Labor Lunch Seminar Spring 2010) and Washington and Lee University; and participants at the World Bank-DFID Poverty and Social Inclusion in the Western Balkans conference, Brussels, for helpful comments and suggestions. Remaining errors and omissions are our own. The first draft of this paper was written while Blunch was a Departmental Guest at Princeton University's Economics Department; the hospitality and support of the Department is gratefully acknowledged. The data were kindly provided by the Statistical Office of the Republic of Serbia (RSO). The assistance of Vladan Božanić, RSO, to help us understand the data better is highly appreciated. The findings and interpretations are those of the authors and should not be attributed to the World Bank, any affiliated institutions, or to the Statistical Office of the Republic of Serbia.
} 


\section{Introduction}

Since the Financial Crisis hit in September 2008 the world has seen one of the worst economic downturns in history-including declining, if not negative, economic growth, declining public and private consumption and massive layoffs of workers.

Better understanding how the Crisis has affected different economies is important for several reasons. First, policy makers need to know the state of the economy, in detail, in order to address and possibly reverse the economic decline. The labor market is especially important here. In particular, analysis of the flows between the different states can help identify factors that are crucial for decreasing the rate of unemployment for a particular group, thus enabling better design of policies to decrease the unemployment rate for that group (Lauerova and Terrel, 2002). Similarly, if, for example, women turn out to have been hit harder than men in terms of lay-offs, maybe public policy interventions should focus more at supporting women in the labor market. Second, severe economic crises such as this one only rarely occurs, so that—still—only little is understood about the workings of economic crises in general. Academics therefore are interested in the opportunity to increase the knowledge of their causes and consequences, whenever a "new" economic crisis hits.

Despite all this, we are only now starting to understand the causes and, especially, the consequences of the Financial Crisis as it pertains to labor markets dynamics. A major reason for this is the paucity of (panel) data that are recent enough to allow examination of the impact of the economic crisis. This is especially true for the former Eastern Europe, where data is even more scarce, again especially for the case of panel data. And panel data are necessary if one really wants to get a handle of the dynamics of the Financial Crisis in the labor market.

In Serbia, however, fortunately rich panel data exist, which allow us to examine the dynamics of the labor market in the context of the Financial Crisis. At the same time, Serbia provides an interesting setting for studying gender disparities in the labor market. This is especially true since although Serbia has experienced rapid economic growth during the recent years, significant gender related disparities have accompanied this process. This development phenomenon can be explained by various social, economic and institutional factors. Two key questions are highlighted in this paper: does the current world economic crisis matter for the Serbian labor market? If so, how does the crisis impact the gender gaps, and what are the determinants of the changes in labor market flows and earnings and earnings growth? In order to answer these two core questions a detailed analysis of the gender disparities in labor market outcomes before and during the crisis will be conducted.

Specifically, this paper examines the flows from employment, unemployment, and inactivity and earnings and earnings growth in the Serbian labor market, analyzing a rich nationally representative panel dataset. The analysis focuses at labor market transitions and earnings growth between October 2008 and October 2009 by conducting rigorous regression analyses using a rich set of variables to control for potentially important factors. In line with the above discussion, the contribution of this paper is three-fold. First, to raise awareness of the gender related disparities pertaining to the Serbian labor market; second, to provide the Serbian government with clear policy recommendations; and third, to add to the academic literature on the consequences of financial crises on the labor market in general and the current/recent Crisis in particular.

The remainder of this paper is structured as follows. The next section presents the data, while section three presents a brief motivation for studying gender and labor market 
issues in Serbia, including the historical background, and discusses recent economic trends in Serbia during the first year of the Financial Crisis with a focus on the labor market. Section four discusses the methodology of this paper, including the conceptual framework and empirical strategy and related issues, while section five presents the results from multivariate analysis of labor market transitions and earnings growth determinants. Finally, section six concludes and discusses policy implications and provides suggestions for further research.

\section{Data}

The Serbian Labor Force Survey is a nationally representative household survey. The survey is conducted as a rolling panel, using a two-stage design - in the first stage, enumeration areas were selected systematically with probability proportional to the size of the population aged 15 and above (the target population) using the sampling frame of the 2002 Census. In the second stage households were selected within the enumeration areas with equal probability (simple random selection). The initial weight arising from the initial sampling design was further corrected ex-post to allow for non-response, aiming at creating sampling weights that make the sample nationally representative (these weights are used in all subsequent estimations). The survey contains information on labor market status, earnings, educational attainment, as well as information on background variables such as age, marital status, and area of residence, which are also important factors in analyses of labor market outcomes.

The analysis in this paper examines the sample of individuals that were surveyed in October 2008 and again in October 2009, thus enabling creating a panel-where the dependent variables are labor market status in October 2009 and earnings growth between October 2008 and October 2009, respectively, and the explanatory variables are individual, household, firm, and community characteristics in October 2008. ${ }^{1}$

Moving to the definition of the variables, again, the dependent variable for the transitions analysis is labor market status in October 2009. This has three possible values - employed, unemployed and economically inactive - and is created from the responses to a series of questions from the questionnaire related to an individual's labor market activity during the reference week (worked for pay or profit, engaged in agricultural production, etc). ${ }^{2}$ Similarly, there are two dependent variables for the earnings analysis: (logged) earnings in levels and earnings growth between October 2008 and October 2009 in percent. The earnings measure is based on information on total earnings of the previous month. ${ }^{3}$

With the gender focus of this paper, individual gender, marital status, and the presence of children in the household have our special interest. The latter is defined as a set of dummies for whether at least on child aged 0-2,3-5, and/or 6-14, respectively, are present in the household.

Educational attainment is measured as the highest level completed, ranging from "Without education" through "PhD." We consider a set of three binary variables, corresponding to the completion of lower secondary, upper secondary, and tertiary education. In terms of the interpretation of subsequent results, it should be noted that this

\footnotetext{
${ }^{1}$ A list of all the variables used in these analyses as well as their definitions is given in Table A1, Appendix A. The definition of variables is discussed in more detail in the remainder of this section.

${ }^{2}$ Details available upon request.

${ }^{3}$ Due to a few extreme values in both tails of the distribution, we censor earnings growth at minus 35 percent and plus 40 percent, respectively.
} 
implies that the base category consists of individuals who completed primary school and below.

The urban dummy and the region of residence cluster fixed effects ${ }^{4}$ capture economic conditions specific to the area (as well as everything else related to the region in question), which are potentially important in explaining labor market flows.

Other variables related to labor market flows not already captured by the variables described previously include age (and, to capture possible non-linearities, age squared), which captures potential general experience.

Following Bellman et al (1995) the previously described explanatory variables are included for examining both the flows out of employment and out of unemployment, as well as the flows out of inactivity (these flows are not considered by Bellman et al, 1995), whereas the different flow analyses include several additional separate explanatory variables, as well.

The analysis of flows out of employment and of earnings also includes job and firm characteristics, namely a set of dummy variables for having no labor contract, job of limited duration, part-time work, firm size and industry. The employment flow analysis also includes salaries in the first period, ${ }^{5}$ as well as a dummy variable for whether an individual was an unpaid family worker in the initial period. ${ }^{6}$

In contrast, the analysis of flows out of unemployment instead additionally includes per capita household income ${ }^{7}$ and a dummy for UI benefit receipt—proxying non-labor income. Again, following Bellman et al (1995), it would have been ideal to be able to include individual income and the amount of UI benefits received instead but this information is not available in this survey.

Lastly, the analysis of flows out of economic inactivity includes per capita household income ${ }^{8}$ but, of course, not the UI receipt dummy variable.

Some of the previous discussion implicitly gives some of the sample restrictions - most importantly, since the emphasis in this analysis is on labor market flows, we initially restrict the sample to the 7,839 individuals 15 years of age and above. Earnings, income, revenue information is not collected on the 848 self-employed individuals in this initial sample, so they have to be dropped (imputation does not appear feasible here, since it is an entire group, the earnings structure of which is likely quite different from formally employed workers). Additionally, information on some observations is collected when it should have (according to the filtering), while information is missing for others, for either the dependent variable or for one or more of the explanatory variables, leading to a final estimation sample of 6,706 observations (2802 females and 2484 males). Similar considerations for the earnings analysis samples leads to sample sizes of 4,864 (2,080 female and 2,784 males) and 4,607 (2,027 female and 2,580 males) for the two cross-section earnings levels samples and to a sample size

\footnotetext{
${ }^{4}$ Due to convergence problems for the male subsample in the inactivity transition analysis, the region fixed effects had to be excluded from this estimation for that one subgroup analysis.

${ }^{5}$ For individuals without salary information, salaries are imputed as the mean salaries of all other workers. To account for imputed salaries, a dummy is added for imputation status.

${ }^{6}$ Since these may be systematically different from other employees, as well as to account for the censoring (the zero salaries imputed to these workers).

${ }^{7}$ Again, for individuals without household income information, per capita incomes are imputed as the mean per capita salaries of all other households. To account for imputed incomes, a dummy is added for imputation status.

${ }^{8}$ And the associated dummy variable for the individuals with imputed per capita household income.
} 
of 1,732 (748 female and 984 males) for the earnings growth analysis estimation sample. ${ }^{9}$ Descriptive statistics for the analysis samples are reported in Appendix B, Tables B1-B5.

\section{Background: Gender and the Labor Market—and Economic Trends during the First Year of the Financial Crisis in Serbia}

This section first gives a brief historical background and motivation for studying gender and labor market issues in Serbia and then goes on to present economic trends during the first year of the Financial Crisis in Serbia focusing on key economic indicators such as GDP growth, value added, wages, employment, and unemployment, as well as gross transitions in and out of employment, unemployment, and inactivity.

\section{Gender and the Labor Market in Serbia ${ }^{10}$}

To better understand the importance of gender in Serbian society-including the labor market - it is important to first to realize that the background (before the transition) is one of formal gender equality, as in other former communist countries. With the collapse of the Berlin Wall in 1989 and the wars followed the transition towards market economythough, according to Babović (2008: 13) "During the last decade of the twentieth century, Serbian society was characterized by a state of blocked transformation that included the obstruction of essential changes in market economy and political democracy by the ruling elite. A profound economic crisis, a deterioration of social institutions, wars with grave economic, social and humanitarian consequences, the impoverishment of a large portion of the population, the expansion of the informal economy and the hampering of the development of civil society, were the main characteristics of Serbian society in this period."

Thus, it is not really until the beginning of the new millennium that the transformation towards a market economy has begun to really take off. Indeed, during the 19990s, Serbia experienced trends of re-traditionalization, which then led to the deterioration of the position of women in the economy overall (Babović, 2008: 13-14). Reform endeavors since the year 2000 have tried to promote gender equality but as of yet has not been successful, as seen by a number of different indicators (Babović (2008: 1415):

(1) The participation of women in government and political life more generally is still quite low-for example, following elections in 2000 and 2003, women comprise only 10.8 percent of the Members of Parliament.

(2) Female labor market participation has deteriorated severely in recent years, from about 70 percent in the socialist times to around 58 percent in recent years; additionally, females are hit harder than males in terms of long-term unemployment and poor entrepreneurship trends.

(3) Female education has improved relative to that of males but at the very highest levels_-Master's and $\mathrm{PhD}$ - females are still lagging behind, accounting for only about 30 to 32 percent.

(4) Due to increased marginalization socially, financially and otherwise, a number of female categories are particularly under pressure in recent years: single

\footnotetext{
${ }^{9}$ The earnings growth levels analysis uses the same panel used in the labor status transitions analysis (or, to be precise, the subsample of it that is employed both in October 2008 and October 2009, so that workers' earnings growth can be calculated), while the earnings levels analysis exploits the full, individual crosssection samples - that is, also includes the non-rolling-panel part in the estimation sample.

10 This section draws heavily upon Babović (2008).
} 
mothers (especially with small and/or special needs children), housewives, elderly, sick and/or disabled women, rural women (especially those without property), displaced and refugee women, uneducated and/or unemployed women.

(5) The private sphere is characterized by a patriarchal division of gender roles, only limited access to financial resources, and a high level of violence.

Altogether, while some key laws related to the above have been established, others - such as the Anti-Discrimination Law and Gender Equality Law - have not (Babović (2008: 15). Females therefore still appear to be at a strong disadvantage in many of the dimensions of Serbian society — not least the labor market. There therefore seem to be ample reason to explore in more detail the nature and correlates of this disadvantage, so as to try to accommodate these potential inequalities. Before moving on to the more analytical analysis pertaining to this, we will first briefly review the main economic trends during the first year of the Financial Crisis in Serbia, again focusing especially on the gender differences.

\section{Economic Trends during the First Year of the Financial Crisis in Serbia}

While the Financial Crisis hit the Western economies around September 2008, with the breakdown of large financial companies in the US, the Crisis spilled over to developing and transition economies a bit later in the Fall of 2008 (Matković et al, 2010). Whereas decreased export demand was a major component of the Crisis for developed and developing countries alike, East European countries were especially hard hit due to the

\section{Table1. Quarterly GDP Growth (Percent)}

\begin{tabular}{ll}
\hline $2008,3^{\text {rd }}$ quarter & 4.6 \\
$2008,4^{\text {th }}$ quarter & 3.0 \\
$2009,1^{\text {st }}$ quarter & -4.2 \\
$2009,2^{\text {nd }}$ quarter & -4.2 \\
$2009,3^{\text {rd }}$ quarter & $-2,3$
\end{tabular}

Source: RSO, Communication 356/2009 (as quoted in Matković et al, 2010: Table 1).

additional and significant dependence on foreign capital inflow (IMF, 2009). Serbia was no exception - and so economic growth slowed down from 4.6 percent in the third quarter to 3.0 percent in the in the fourth quarter of 2008, before it finally became negative from the first quarter of 2009 onwards (Table 1).

The labor market was an important part of these overall economic developments in Serbia - with different sectors being hit to various degrees. From Table 2, it can be seen how already in the last quarter of 2008 economic activity declined substantially in manufacturing, power and construction. These tendencies continued in the first quarter of 2009, where the number of sectors with negative economic growth increased to now also include mining and quarrying, wholesale and retail trade, and hotels and restaurants. The decline continued into the second quarter of 2009, although some sectors also experienced moderate growth. 
Table 2. Gross Value Added: By Sector and Total (Percent)

\begin{tabular}{llll}
\hline & $\begin{array}{l}2008,4^{\text {th }} \\
\text { quarter }\end{array}$ & $\begin{array}{l}2009,1^{\text {st }} \\
\text { quarter }\end{array}$ & $\begin{array}{l}2009,2^{\text {nd }} \\
\text { quarter }\end{array}$ \\
\hline Agriculture, hunting and forestry; fishing & 9.0 & 1.6 & 3.2 \\
Mining and quarrying & 2.7 & -7.3 & -9.0 \\
Manufacturing & -4.4 & -20.9 & -20.0 \\
Electricity, gas and water supply & -3.9 & -1.0 & -1.3 \\
Construction & -3.4 & -13.8 & -16.1 \\
Wholesale and retail trade, repairs & 4.3 & -6.3 & -8.0 \\
Hotels and restaurants & 1.8 & -9.2 & -11.8 \\
Transport, warehousing and & 8.4 & 4.1 & 7.5 \\
communications & & & \\
Financial intermediation & 8.3 & 6.1 & 5.9 \\
Real estate and rental & 3.5 & 1.3 & 2.7 \\
Other services & 2.1 & 2.3 & 1.7 \\
& & & \\
Total, gross value added & 3.2 & -3.2 & -2.8 \\
\hline
\end{tabular}

Source: RSO, unpublished document (as quoted in Matković et al, 2010: Table 2).

With almost all sectors experiencing negative growth, a substantial reduction of employment resulted as a natural consequence. Total employment in Serbia decreased from 2.84 million in April 2008 to 2.64 million in April 2009-or just below 7 percent; in October 2009 (the end period of the analysis in this paper) total employment decreased further to 2.59 million (Matković et al, 2010).

Table 3 presents the trends in employment, unemployment and inactivity over the course of the 12 months from October 2008 to October 2009 covered by the analysis in this paper - total, as well as by gender. From the table, employment decreased overall over the 12 months: from 37.6 percent to 35.4 percent - or 2.2 percentage-points. Only one percentage-point of this went into an increase of unemployment, however, so that the remaining 1.2 percentage-points went into inactivity. The experiences were different across gender, however, with males being relatively more likely to become unemployed - with employment decreasing by about 3 percentage-points, or about double that of females. 
Table 3. Trends in Employment, Unemployment and Inactivity: Total and By Gender (Percent)

\begin{tabular}{lrrr}
\hline & Total & Female & Male \\
\hline & & & \\
Oct 2008: & & & \\
\hline Employed & 37.6 & 32.1 & 44.4 \\
Unemployed & 8.8 & 7.9 & 9.8 \\
Inactive & 53.6 & 60.0 & 45.8 \\
& & & \\
Oct 2009: & & & \\
\hline Employed & 35.4 & 30.5 & 41.5 \\
Unemployed & 9.8 & 8.8 & 10.9 \\
Inactive & 54.8 & 60.7 & 47.6 \\
\hline
\end{tabular}

Notes: $\mathrm{E}=$ employment, $\mathrm{U}=$ unemployment, $\mathrm{N}=$ inactive (not in the labor force). Number of observations: full sample $=6,706$; females $=3,668$; males $=3,038$. Estimations incorporate sampling weights.

Source: Serbia Labor Force Survey (October 2008 and October 2009 Rounds).

To go a bit deeper into the composition of these trends, we disaggregate employment and inactivity (Table 4). From the table, a few observations stand out in particular. First, most sectors shrunk in terms of their share of overall employment, with the public sector as a notable exception. Second, the share of most sectors among the employed

decreased for most sectors, again with the public sector as a notable exception-and here the share of public sector employment increased more for females than for males. Third, among the inactive, the only group (apart from "other") to increase overall is discouraged workers, by 0.6 percentage points - slightly more for males ( 0.7 percentage points) than for females ( 0.5 percentage points).

Table 4. Trends in Employment and Inactivity by Sector and Type: Total and By Gender (Percent)

\begin{tabular}{lrrr|rrr}
\hline & \multicolumn{3}{c|}{ October 2008: } & \multicolumn{3}{c}{ October 2009: } \\
\hline & Total & Female & Male & Total & Female & Male \\
\hline & & & & & & \\
Employed: & & & & & & \\
Agriculture & 13.8 & 19.1 & 9.2 & 13.8 & 18.2 & 9.9 \\
Manufacturing, Mining & 26.8 & 18.9 & 33.8 & 25.2 & 16.9 & 32.7 \\
Construction & 5.8 & 2.0 & 9.2 & 5.5 & 1.9 & 8.7 \\
Trade and services & 14.7 & 16.7 & 12.9 & 14.2 & 16.5 & 12.2 \\
Hotel and Restaurants & 3.7 & 4.4 & 3.0 & 3.2 & 3.8 & 2.7 \\
Transport & 6.3 & 2.9 & 9.3 & 6.2 & 2.6 & 9.5 \\
Financial and real estate & 5.2 & 5.9 & 4.5 & 5.6 & 6.2 & 5.0 \\
Public sector & 19.9 & 26.8 & 13.7 & 21.4 & 29.1 & 14.4 \\
& & 8 & & & &
\end{tabular}




\begin{tabular}{lrrr|rrr} 
Other & 4.0 & 3.4 & 4.5 & 4.9 & 4.9 & 5.0 \\
\hline Total & 100.0 & 100.0 & 100.0 & 100.0 & 100.0 & 100.0 \\
& & & & & & \\
Inactive: & & & & & & \\
Discouraged & 5.7 & 5.9 & 5.4 & 6.3 & 6.4 & 6.1 \\
Retired & 34.8 & 31.6 & 39.9 & 34.4 & 31.8 & 38.5 \\
Student & 18.2 & 14.5 & 24.3 & 16.9 & 13.5 & 22.2 \\
Looking after children & 2.9 & 4.4 & 0.4 & 2.9 & 4.6 & 0.2 \\
Other & 38.4 & 43.6 & 30.0 & 39.6 & 43.7 & 33.0 \\
\hline Total & 100.0 & 100.0 & 100.0 & 100.0 & 100.0 & 100.0 \\
& & & & & & \\
\hline
\end{tabular}

Notes: Number of observations: full sample $=6,706$; females $=3,668$; males $=3,038$. Estimations incorporate sampling weights.

Source: Serbia Labor Force Survey (October 2008 and October 2009 Rounds).

Moving to the dynamics of the labor market in Serbia, Table 5 presents the gross transition probabilities for the full sample and across gender. From the table, the employment transition dynamics are quite similar for females and males: about 90 percent stayed employed in October 2009, with about 4 percent moving into unemployment and about 6 percent into economic inactivity. However, slightly less females (4.1 percent) than males (4.4 percent) moved into unemployment, while slightly more females (6.6 percent) than males ( 6.3 percent) moved into inactivity.

The unemployment transition dynamics, however, differs somewhat across genders. Here, 88.4 of females stay unemployed in October 2009, while only 84.8 percent of males stay unemployed. Males, at 10.5 percent, are more likely to become employed in October 2009 than females, at 7.8 percent. The transition into inactivity is roughly similar, at 3.9 percent for females and 4.6 for males.

The inactivity transition dynamics again are quite similar across gender, though females, at 97.0 percent, are slightly less likely to move out of inactivity than males, at 96.8 percent. About 2 percent moved from inactivity into employment and about 1 percent moved from inactivity into unemployment. Summing up, substantial fractions stayed - in October 2009 - in the labor market status they were in the year before, in October 2008, though females seems to have been somewhat at a disadvantage in terms of not being able to move out of unemployment and inactivity to the same degree as males.

Table 5. Labor Market Transition Probabilities: Total and By Gender (Percent)

\begin{tabular}{lrrr|rrr|rrr}
\hline & EE & EU & EN & UE & UU & UN & NE & NU & NN \\
\hline Full sample & 89.3 & 4.3 & 6.5 & 9.2 & 86.6 & 4.2 & 2.0 & 1.1 & 96.9 \\
Females & 89.3 & 4.1 & 6.6 & 7.8 & 88.4 & 3.9 & 2.0 & 1.0 & 97.0 \\
Males & 89.2 & 4.4 & 6.3 & 10.5 & 84.8 & 4.6 & 1.9 & 1.3 & 96.8 \\
\hline
\end{tabular}

Notes: $\mathrm{E}=$ employment, $\mathrm{U}=$ unemployment, $\mathrm{N}=$ inactive (not in the labor force). Number of observations: full sample $=6,706$; females $=3,668$; males $=3,038$. Estimations incorporate sampling 
weights.

Source: Serbia Labor Force Survey (October 2008 and October 2009 Rounds).

But what might some of the underlying causes of the differential trends among female and male labor market transitions be? By presenting employment composition and employment and earnings growth by sector and firm size, Table 6 provides some evidence on possible causes. First, males were much more likely to be employed in manufacturing, power, and construction - which, as seen from the table and also discussed previously, were among the sectors affected the most in the beginning of the Financial Crisis. Second, males were also more likely to be employed in larger firmswhich again are more likely to be in the modern, formal sector-which again also are seen to account for most of the employment-unemployment transitions in Serbia during the beginning of the Financial Crisis (also see Matković et al, 2010: 29).

Together, this indicates that some of the higher increase of male unemployment relative to female unemployment has a sectoral component. Third, there appears to be a substantial gender gap in salaries in Serbia, males earning about 21.5 percent more than females, on average. In turn, this might help explain the higher persistence in the unemployment of females, due to a discouraged worker effect: when losing a job, the incentive to return to employment is relatively lower than it is for males due to the relatively lower remuneration.

At the same time, since females often will be secondary breadwinners in a household, they will have more flexibility in terms of leaving the job market in times of crisis, where "job stayers" can expect to experience earnings losses (at least on average). This is supported by the data on earnings growth in the bottom of Table 6, which shows that males experienced substantially higher earnings losses than females, by about 1.45 percentage-points. It is possible, therefore, that some of the females who would have experienced even higher earnings decreases have chosen to withdraw from the labor market, thus pushing down the average earnings loss among women. Males, being the primary breadwinner in most households, would not have this opportunity and would therefore seem to have to "stay put" on the labor market, even in the face of large(r) earnings losses than those experienced by (staying) females. Once again this indicates that both males and females were hurt by the Financial Crisis but in quite different ways.

Table 6. Employment Composition in October 2008 and Employment and Earnings Growth from October 2008 to October 2009 by Sector and Firm Size

\begin{tabular}{lrr|rr|rr}
\hline & Share (Mean) & \multicolumn{2}{l|}{$\begin{array}{l}\text { Employment growth } \\
\text { (percent) }\end{array}$} & \multicolumn{2}{l}{$\begin{array}{l}\text { Earnings growth } \\
\text { (percent) }\end{array}$} \\
\hline & Females: Males: & Females: & Males: & Females: & Males: \\
\hline & & & & & & \\
Sector of employment: & & & & & & \\
Agriculture & 0.203 & 0.095 & -9.5 & 0.0 & -19.7 & -1.6 \\
Manufacturing-Mining-Electricity & 0.193 & 0.347 & -15.3 & -10.0 & -2.8 & -3.5 \\
Construction & 0.019 & 0.091 & -10.4 & -12.1 & -5.8 & -7.0 \\
Trade/Services & 0.169 & 0.130 & -5.9 & -12.0 & -0.4 & -2.4 \\
Hotels/Restaurants & 0.044 & 0.029 & -16.8 & -16.8 & -1.7 & -5.3 \\
Transports & 0.031 & 0.089 & -15.2 & -4.9 & 0.5 & -1.7 \\
& & & & &
\end{tabular}




\begin{tabular}{lrr|rr|rr} 
Financial/Real Estate & 0.048 & 0.038 & -0.2 & 4.0 & 1.9 & -4.8 \\
Public Sector & 0.265 & 0.135 & 3.2 & -1.8 & -1.7 & -2.2 \\
Other Sector & 0.029 & 0.046 & 38.1 & 3.7 & 2.4 & -2.2 \\
& & & & & & \\
& & & & & & \\
Firm size: & 0.396 & 0.266 & -2.6 & -1.5 & -2.7 & -1.8 \\
Firmsize 0-5 & 0.251 & 0.270 & -6.8 & -9.2 & -1.7 & -4.0 \\
Firmsize 6-19 & 0.183 & 0.223 & -9.9 & -8.8 & 0.0 & -3.4 \\
Firmsize 20-99 & 0.125 & 0.170 & -11.4 & -8.4 & -2.2 & -3.9 \\
Firmsize 100+ & 0.012 & 0.020 & 22.9 & 5.4 & -1.8 & -1.8 \\
Firmsize not sure: 10 or less & 0.034 & 0.050 & 9.6 & -8.8 & -4.4 & -2.2 \\
Firmsize not sure: 11 or more & & & & & & \\
& $20,222.8$ & $24,560.9$ & & & -1.78 & -3.23 \\
Real earnings & $4,338.2$ & & & 1.45 & \\
Real earnings gender gap & & &
\end{tabular}

Notes: Number of observations, columns 1-4: females $=3,668$; males $=3,038$. Number of observations, columns 5-6: females $=748$; males $=984$. Estimations incorporate sampling weights.

Source: Serbia Labor Force Survey (October 2008 and October 2009 Rounds).

Finally, we explore what happened to the main job characteristics of the primary and secondary job of workers (Table 7). ${ }^{11}$ From the table, the share of workers who did not have a labor contract and who had work of limited duration both decreased over the period. One interpretation here is that these were the types of workers that were first laid-off due to the Financial Crisis. Part-time work increase slightly among females (from 2.2 to 2.6 percent) while it decreased among males (from 3.1 to 2.0 percent). The hours worked in the main job stayed quite stable over the period, as did also the incidence of workers with a secondary job (though males experienced a slight increase here, from 6.4 to 7.1 percent). The actual hours worked in the secondary job decreased by about two hours for both females and males - though it is of course hard to determine whether this is supply or demand driven.

Table 7. Job Characteristics of Primary and Secondary Job for Workers Who Were Employed in October 2008 and/or October 2009 (Means)

\begin{tabular}{lll|lc}
\hline & \multicolumn{2}{c|}{ Females: } & \multicolumn{2}{c}{ Males: } \\
\hline & October 2008: & October 2009: & October 2008: & October 2009: \\
\hline & & & & \\
Main Job: & 0.059 & 0.037 & 0.098 & 0.061 \\
No labor contract & 0.110 & 0.102 & 0.147 & 0.118 \\
Limited duration & 0.022 & 0.026 & 0.031 & 0.020 \\
Part-time & 41.7 & 41.4 & 43.1 & 43.2 \\
Usual hours (per week) & 40.4 & 43.1 & 43.1 \\
Actual hours (reference week) & 40.9 & 4 &
\end{tabular}

${ }^{11}$ This is done using the cross-sectional estimation samples that are also used to estimate the Mincer-type earnings (levels) equations in the multivariate analysis section. 


\begin{tabular}{lll|ll} 
Secondary Job: & & & \\
Has secondary paid job & 0.029 & 0.028 & 0.064 & 0.071 \\
Actual hours (reference week) & 14.3 & 12.1 & 19.0 & 17.0 \\
$\mathrm{~N}$ & 2,080 & 2,027 & 2,784 & 2,580 \\
\hline
\end{tabular}

Notes: Estimations incorporate sampling weights.

Source: Serbia Labor Force Survey (October 2008 and October 2009 Rounds).

The results on the transition probabilities and earnings levels already tell part of a story of females being disadvantaged in the Serbian labor market in terms of moving out of the two undesirable states - unemployment and economic inactivity - and in terms of remuneration relative to males during the first year of the financial crisis, while at the same time males have been hit relatively harder in terms of unemployment and earnings losses (if remaining employed). The descriptive analysis has also helped tell the overall story of the recent developments in the Serbian labor market while at the same time hinting at some explanations of the different experiences for males and females. We will now take the analysis a step further by estimating multinomial logits of transition probabilities and earnings growth regressions, controlling for a host of potential determinants simultaneously to try to shed additional light on the complex nature of labor market dynamics in Serbia.

\section{Methodology}

This section reviews the methodology applied in this paper. First, we discuss the conceptual framework to shed more light on what might drive labor market transitions and earnings; this is then followed by a discussion of the empirical strategy and related issues.

The traditional economic approach to examining labor market flows has frequently regarded the flow from one labor market state to another as a dynamic process governed by a Markov process (Marston, 1976; Toikka, 1976; Heckman, 1981; Bellman et al, 1995; Gong et al, 2000; Tasci and Tansel, 2005). Suppose an individual $i$ can be in one of $J$ different labor market states (here, $J=3$ : employed, unemployed, inactive) at time $t$. Further, assume that conditional on being in a specific labor market state $j$, an individual's indirect utility is a function of education $(E)$; other observed individual background characteristics including age, gender and geographic location $(B)$; and unobserved individual characteristics including ability $(\delta)$, leading to the following simple model of individual $i$ 's indirect utility of being in labor market state $j$ at time $t$ :

$V_{j}=V\left(E_{i t}, B_{i t}, C_{i t}, \delta_{i j}\right)$

Individual $i$ chooses labor market state $j$ if the indirect utility of status $j$ exceeds that of all the other possible labor market states. ${ }^{12}$ In turn, this choice is affected by individual, household, and community characteristics. For example, individuals with more education are more likely to be employed than to being either unemployed or

\footnotetext{
${ }^{12}$ Due to rationing and barriers to entry into employment there might not be much of a choice between this and unemployment. There still is a choice between being in the labor force and being economically inactive, however.
} 
economically inactive, due to higher foregone earnings (again, assuming that any jobs are available). Females generally earn lower earnings than males (Blau, 1996) and so may be more expected to be more likely to be unemployed or economically inactive than males (i.e., due to having lower opportunity cost). This is perhaps especially true when children, especially smaller children are present in the household, since these may cause the female to leave the labor market altogether, at least temporarily, since smaller children can be assumed to require more time-intensive child care (Ribar, 1992). Indeed, in the context of a financial crisis, we suggest that the effect of having children present in the household could effectively be viewed as giving rise to an "enhanced" discouraged worker effect. Marital status could affect labor market status in several possible ways. In a "traditional" society, with the male as the main bread-winner, married males can be expected to be more likely to work and females less so. On the other hand, an unmarried woman, especially if she has children, could face serious economic stress and therefore a great need to work, also.

Conditional on being employed in both periods, then, an individual will experience earnings growth - either positive (gains) or negative (losses). After a Crisis, negative overall earnings growth can be expected, i.e. "everybody loses overall." But some may increase their earnings. In any case, it is useful for policy makers to understand (1) who the winners and losers are and (2) how much the winners gained and the losers lost.

A potentially fruitful way to understand the related issues is the human capital framework, where an individual invests in education with an eye towards the expected future earnings stream (Becker, 1964; Mincer, 1974). The expected future earnings stream, of course, includes earnings during times of crisis, also, so that the same intuition underlying the traditional human capital framework (where the possibility of economic crisis typically - if ever - was not explicitly incorporated) may be applied to the analysis carried out in this paper.

Hence, individuals with certain levels of education or from certain industries, for example, may be particularly hard hit during times of crisis in terms of their earnings outcomes (again, if they are fortunate enough to remain employed, of course). One might here conjecture that individuals with lower levels of education and/or from industries who are more affected by diminishing consumer demand following the Crisis will be more likely to experience earnings loses (as an alternative to losing their earnings altogether by being laid-off). Pertinent factors associated with earnings growth here therefore include educational attainment and industry. However, in keeping with the theme of this paper, the gender component also potentially is an important factor associated with earnings growth. For example, males being the main breadwinners in most societies, may be forced to stay employed in the face of earnings losses, whereas females may decide instead to stay home and attend to small(er) children, while waiting for a better paid job, or to drop out of the labor force altogether. Hence, one would expect to see higher job losses among males than among females, due to the formers stronger ("forced") labor force attachment - and therefore also that and individual's gender is an important determinant of whether an individual experienced an earnings loss or not (conditional on remaining employed).

\section{Estimation Strategy and Issues:}

The conceptual framework discussed in the previous subsection suggests that education and gender can directly affect the labor market state of an individual and also suggests 
additional factors that are potentially important in explaining labor market flows and therefore should be included in the empirical specifications. ${ }^{13}$ For the transitions analysis, the empirical analysis will examine the relationship between labor market flows and individual characteristics using the multinomial logit model. Specifically, if one assumes that the errors across choices in equation (1) above are independently and identically distributed such that $F\left(\delta_{i i}\right)=\exp \left(e^{-\delta_{i j}}\right)$, this yields the multinomial logit model. For the earnings (level) and earnings growth analysis OLS will be used.

Estimation-wise, we note the potential endogeneity problems related to several of the included explanatory variables in both the transitions and the earnings growth analysis, especially education (both analyses), earnings (employment transitions, only), income (unemployment and economic inactivity transitions, only) and the presence of children in the household (transitions analyses, only). However, as we do not have available in this dataset any variables that may potentially act as instruments, it does not appear feasible to try to address this problem using instrumental variables methods. As a result, we must interpret any subsequent results with caution and hence not give them a causal interpretation but rather as merely reflecting associations with labor market outcomes. It should be noted, however, that since the estimations use explanatory variables for the first period (i.e. October, 2008) to explain the labor market state of the second period (October, 2009) the variables are at least predetermined, so that the simultaneity-part of the endogeneity concerns are somewhat dampened. ${ }^{14}$

\section{Multivariate Analysis of Labor Market Transitions and Earnings Growth}

This section discusses the multivariate results. There are two main analyses: one of labor market transitions, and one of Mincer-type earnings equations in two flavors-earnings levels and earnings growth, respectively. The motivation for these analyses is to identify the "winners and losers" in terms of these labor market outcomes, so that policy makers in Serbia can adequately mitigate these discrepancies. We begin with an analysis of the determinants of the labor market flows discussed earlier (Table 5). This part involves three sub-analyses, namely of transitions out of employment, out of unemployment, and out of inactivity. We then move on to an analysis of the determinants of earnings and earnings growth. ${ }^{15}$ Due to the emphasis of this study on the gender aspects of labor market outcomes in Serbia, the main emphasis will be on the gender dimension; also, all analyses are performed using fully interacted models with female dummies. Lastly, it should be noted that due to the wealth of results stemming from the rich set of controls used in this analysis, this discussion is necessarily relatively selective, highlighting only the most noteworthy results (though the full set of results is given in the tables).

\section{(A) Labor Market Transitions:}

Table C1 presents the results from the multinomial logits of transition probabilities, with two columns each for employment transitions, (base group: employed), unemployment

\footnotetext{
${ }^{13}$ Since omission of these factors would otherwise lead to omitted variables bias. A list of all the variables used in these analyses as well as their definitions is given in Table A1, Appendix A. The definition of variables is discussed in more detail in the next section.

${ }^{14}$ Still leaving, of course, potential endogeneity issues related to omitted variables and/or measurement error.

${ }^{15}$ Again, in addition to being of interest in and by itself due to the impact of workers' livelihoods from the drop in earnings following the Financial Crisis, the drop in earnings (negative earnings growth) is one of the potential underlying causes of the labor market transitions in Serbia during the Crisis.
} 
transitions (base group: unemployed), and economically inactive (base group: economically inactive).

\section{(i) Flows out of Employment:}

Consistent with the earlier more descriptive analysis, there are strong gender components in the transitions out of employment (Table C1). While older workers (the 65 years and above group) are both less likely to become unemployed and to drop out of the labor force than young workers (workers 15-24 years of age, the reference group) - in turn indicating that the delayed retirement of workers of retirement age is a key element in coping with the Financial Crisis in Serbia-older females are even less likely to become unemployed (at about 4 percentage-points), though more likely to retire than males (at about 43 percentage-points). This is consistent with the retirement age of females being five years lower than that of males in Serbia (Arandarenko and Avlijas, 2010). Single females appear to be a particularly hard hit group, at almost 3 percentage-points more likely to move into unemployment. Education acts as a buffer for females, however: when having completed tertiary education, females are less likely to move into unemployment than are males (at about 2 percentage-points).

Workers holding jobs with no labor contract or of a limited duration are more likely to move into unemployment. Females are here somewhat better off than males, even if the differences are small. The presence of children in the household turns out to be important, and with substantial gender differences. While workers with children are more hit in terms of unemployment than workers without children, females are somewhat less hit than are males for younger children, while for older children they are a bit worse off (at about 1 percentage-point). Female workers are much more likely to transition into inactivity when having young children present in the household-again reflecting the higher incentives to stay home and tend to children rather than either remaining employed (with resulting earnings losses) or to spend time searching for a new job. Again, this is consistent with the notion that younger children needs relatively more time than older children in their care (Ribar, 1992). So having small children in the household adds to the Crisis impact to effectively give a stronger total discouraged worker effect for women.

In line with the earlier discussion, manufacturing-mining-power and construction industries bear a large amount of the increase in both unemployment and inactivity. However, the burden is borne differently by gender, with females from these industries being both less likely to become unemployed than males (possibly due to predominantly occupying clerical positions, which may be less likely to be down-sized relative to unskilled "front-line:" positions, where males likely hold the larger share) and again more likely to drop out of the labor force than males.

Turning to firm size, the estimated coefficients, while mostly statistically significant, are mostly substantively small. The higher the earnings, the lower the probability of becoming unemployed, again reflecting the fact that the bulk of the unemployment burden in Serbia was borne by the bottom of the earnings distribution. Lastly, urban areas were hit harder than rural areas both in terms of unemployment and inactivity, with females being hit harder in terms of unemployment though not as hard in terms of inactivity.

\section{(ii) Flows out of Unemployment:}

Again consistent with the earlier more descriptive analysis, even when controlling for 
other factors, females are both less likely to become employed and more likely to become inactive than are males (Table C1). Married females are both less likely to become employed and more likely to drop out of the labor force. This is again consistent with females - as the secondary breadwinners - having greater incentive to stay home either unemployed or inactive than to take an earnings loss in the labor market. When infants or small children are present in the household, females are generally less likely to become employed and more likely to become inactive - again consistent with females tending to children rather than facing earnings losses in the labor market, and also again reflecting the role of the main breadwinner (the male) being strengthened in the presence of infants or small children in the household. There is a strong increase in the probability of becoming employed among the higher educated and some effect of an increase of household income on both employment and inactivity.

Receiving unemployment benefits or assistance affects the flows into employment and/or inactivity substantially, and with a strong gender component present. While UI receipt increases the probability of employment by about 28 percentage-points and decreases inactivity by about 6 percentage-points, respectively, overall the probability of employment decreases for females by about 9 percentage-points, while inactivity for females increases by about 92 percentage-points (again, this is a marginal effect, which is why it can be so implausibly high in the first place - for practical purposes it may be useful to merely consider the estimated effect "large"). Interestingly, the large negative estimated coefficient for individuals for urban areas overall hides opposing effects for females and males - with females from urban areas being both more likely to become employed and to become inactive than males.

\section{(iii) Flows out of Inactivity:}

Lastly, the results for the multinomial logit of inactivity flows are also presented in Table C1. In line with the descriptive analysis which indicated only little movement out of inactivity (as can also seen from the descriptive statistics for this analysis in Appendix B, Table B3), the results for this part of the analysis are mostly quite weak in substantive terms. A few results stand out, however. Education increases the probability of becoming employed, though much more so for females at the lower levels and more so for males at the higher levels. Also, females with small children present in the household are less likely to move into employment and more likely to move into unemployment.

\section{(B) Mincer Earnings Equations}

The results from Mincer-type earnings equations are presented in Table C2. From the table, it is clear that female workers have been disadvantaged in terms of earnings for the period overall - at 19.1 percent in October 2009, then decreasing to 14.2 percent in 2009. ${ }^{16}$ Further, the younger workers consistently have obtained higher earnings throughout the period relative to the youngest workers (the 15-24 year old cohort), whereas the older workers have earned less. Workers of retirement age earned substantially less by the beginning and end of this period-and the 55-64 year old cohort experienced a severe drop in earnings.

In addition to being hit hard overall in terms of earnings, females also experience lower wages than males across many of the age cohorts. Consistent with earlier findings

\footnotetext{
${ }^{16}$ Using the formula: gender gap $=[\exp ($ coefficient $-0.5 *$ variance $($ coefficient $))-1]$ for the coefficient and variance of the female dummy in the specifications with the female dummy, only (and no interactions) in Table C2, Appendix C, see Kennedy (1981).
} 
from other countries and time periods, the more educated workers also receive higher earnings. Interestingly, this is even more pronounced for female-in other words, education helps to decrease the wage inequality between males and females. The workers who have jobs with undesirable characteristics - such as no labor contract, limited duration, and part-time — at the same time also are hit on their earnings, thus ending up being "hit twice."

Interestingly, while this is even more pronounced for females in jobs with no labor contract, female workers in jobs of limited duration or in part-time jobs earn more than their male counterparts, thus being at least partially compensated for the adverse job characteristics. Perhaps surprisingly, workers in some of the industries hit hardest in terms of unemployment - such as manufacturing, mining, and construction, as discussed previously - are better off in terms of earnings (relative to the reference industry, agriculture). The evidence across gender here is more mixed.

\section{(C) Earnings Growth}

The results from Mincer-type earnings growth equations are presented in Table C3. In terms of earnings growth, Table $\mathrm{C} 3$ (first column of results) reveals that females experienced positive earnings growth relative to males, at about 1.45 percentage-points overall (mirroring the "raw" gender earnings growth gap from the bottom of Table 6). Again, this is conditional on remaining employed and as we saw earlier, females were both more likely to becoming unemployed and inactive than males over this period overall. Additionally, it has been argued that employed women are a much more selective group than working men (Arandarenko and Avlijas, 2010), so that women are still very much "swimming upstream" here.

However, there are several (combinations of) individual characteristics for which females do better than males, earnings growth-wise-in turn, this is what decreases the coefficient for the female dummy when first including explanatory variables (the second column of results in Table C3) and then finally makes it flip sign when moving to the fully interacted specification (the third column of results in Table C3).

For example, especially some of the sectoral premiums are really high for females. Also, similar to what was found for the earnings (levels) regressions, the gender earnings growth gap narrows with education, though it appears to level off for higher levels of education. Turning to the sectoral experiences, females experienced higher earnings growth than males across all sectors, relative to agriculture (the reference sector). In terms of sectoral differences, public sector workers are among the big winners, experiencing higher increases in percentage terms - and again more so for females than for males. Workers in urban areas again were harder hit in terms of wage growth, also, negative earnings growth, relative to workers from rural areas.

\section{Conclusion}

This paper examines labor market transitions, earnings (levels), and earnings growth, and their correlates using a recent panel data set for Serbia during the Financial Crisis, something which has previously not received much attention due mainly to a paucity of data.

Estimation of gross transition probabilities reveals that females are disadvantaged in the Serbian labor market in terms of moving out of the two undesirable statesunemployment and economic inactivity - relative to males during the first year of the financial crisis. Multinomial logit estimations of employment, unemployment, and 
inactivity transitions and OLS regressions of earnings and earnings growth reveal substantial gender differences related to individual, job, and firm characteristics, with females again being disadvantaged overall. The big loser in terms of employment, earnings and earnings growth in Serbia following the Financial Crisis are the ones already under pressure: the less educated, parents, workers with already low job security and/or no social insurance coverage - and, again, women, who are already struggling against traditional gender roles and a substantial earnings gap. While women were found to experience lower earnings losses than men following the Financial Crisis, it should again be kept in mind that this was from a much lower base than men and, again, that working women in Serbia also are a much more select group than working men (Arandarenko and Avlijas, 2010).

Two main policy implications seem to come out of this. First, that females - as has also been found in other countries - would seem to require special attention in terms of public policy addressed toward the provision of, for example, education, training and child care specifically targeted towards women. However, second, this need for gender sensitive public policies seems to have been exacerbated by the Financial Crisis, so that female workers now appear to require even more attention than before the Crisis.

In terms of future research, we suggest that - again given the paucity of data in this line of research for this region, so far-more funds are devoted to collect high quality data such as the data analyzed here to be able to understand better the role of gender in the labor market in the former centrally planned economies. And here especially the role of gender during times of crisis, such as the recent Financial Crisis. 


\section{References}

Arandarenko, M. and S. Avlijas, S. (2010) "Behind the Veil of Statistics: Wage Trends Before and After the Crisis in Serbia," Study commissioned by ILO, Belgrade.

Babović, Marija (2008) "The Position of Women on the Labour Market in Serbia," Belgrade: Gender Equality Council, Government of the Republic of Serbia and United Nations Development Programme, Serbia.

Becker, Gary S. (1964) Human Capital, Chicago: University of Chicago Press.

Bellman, Lutz, Saul Estrin, Hartmut Lehmann and Jonathan Wadsworth (1995) "The Eastern German Labor Market in Transition: Gross Flow Estimates from Panel Data," Journal of Comparative Economics 20: 139-170.

Blau, Francine D. (1996) "Where Are We in the Economics of Gender? The Gender Pay Gap,” NBER Working Paper No. 5664, Cambridge, Mass.: National Bureau of Economic Research.

Gong, Xiadong, Arthur van Soest and Elizabeth Villagomez (2000) "Mobility in the Urban Labor Market: A Panel Data Analysis for Mexico," IZA Discussion Paper No. 213.

Heckman, J. (1981) "Statistical Models for Discrete Panel Data," in Manski, C. and D. McFadden (eds) Structural Analysis of Discrete Data with Econometric Applications, London: MIT Press.

Huber, P. J. (1967) "The Behavior of Maximum Likelihood Estimates under Nonstandard Conditions," in: Lucien M. Le Cam and Jerzy Neyman (Eds.) Proceedings of the Fifth Berkeley Symposium on Mathematical Statistics and Probability Vol. 1, Berkeley, CA: University of California Press.

IMF (2009) World Economic Outlook, Washington, DC: International Monetary Fund.

Kennedy, P. (1981) "Estimation with Correctly Interpreted Dummy Variables in

Semilogarithmic Equations," American Economic Review, 71: 801.

Lauerova, J.S. and K. Terrel (2002) "Explaining Gender Differences in Unemployment with Micro Data on Flows in Post-Communist Economies," IZA Discussion Paper No. 600.

Marston, S.T., (1976) "Employment Instability and High Unemployment Rates," Brookings Papers on Economic Activity 1: 169-203.

Matković, Gordana, Boško Mijatović and Marina Petrović (2010) Impact of the Financial Crisis on the Labor Market and Living Conditions Outcomes, Mimeo, Center for Liberal-Democratic Studies.

Mincer, Jacob (1974) Schooling, Experience and Earnings, New York: National Bureau of Economic Research.

Ribar, David (1992) "Child Care and the Labor Supply of Married Women: Reduced Form Evidence," Journal of Human Resources 27(1): 134-165.

Tasci, H. Mehmet and Aysit Tansel (2005) "Unemployment and Transitions in the Turkish Labor Market: Evidence from Individual Level Data," IZA Discussion Paper No. 1663.

Toikka, Richard (1976) "A Markovian Model of Labor Market Decisions by Workers," American Economic Review 66(5): 821-834.

White, H. (1980) "A Heteroskedasticity-Consistent Covariance Matrix Estimator and a Direct Test for Heteroskedasticity," Econometrica 48(4):817-830. 


\section{APPENDIX A: Definition of Variables and Specification of Explanatory Variables in Regression Models}

Table A1. Definition of Variables and Specification of Explanatory Variables in Regression Models

\begin{tabular}{|c|c|c|c|c|c|}
\hline Variable name: & \multirow[t]{3}{*}{ Definition: } & \multicolumn{4}{|c|}{$\begin{array}{l}\text { Included as explanatory } \\
\text { variable in estimation? }\end{array}$} \\
\hline \multirow[b]{2}{*}{ Dependent variables: } & & \multicolumn{3}{|c|}{$\begin{array}{l}\text { Labor Market } \\
\text { Transitions: }\end{array}$} & \multirow{2}{*}{$\begin{array}{l}\text { Earnings/ } \\
\text { Earnings } \\
\text { Growth: } \\
\end{array}$} \\
\hline & & & & & \\
\hline $\begin{array}{l}\text { Labor market status (in Oct. } \\
\text { 2009) } \\
\text { Earnings growth (Oct. 2008-Oct. } \\
\text { 2009) } \\
\text { Log real earnings (Oct. 2008, Oct. } \\
\text { 2009) }\end{array}$ & $\begin{array}{l}1 \text { if employed, } 2 \text { if unemployed, } \\
3 \text { if inactive } \\
\text { Earnings growth, Oct. 2008-Oct. 2009, } \\
\text { in percent } \\
\text { Log real earnings in the previous month }\end{array}$ & $\mathrm{X}$ & $\mathrm{X}$ & $\mathrm{X}$ & $\begin{array}{l}X \\
X\end{array}$ \\
\hline \multicolumn{6}{|l|}{ Explanatory variables: $:^{17}$} \\
\hline Female & 1 if female; 0 otherwise & $\mathrm{X}$ & $\mathrm{X}$ & $\mathrm{X}$ & $\mathrm{X}$ \\
\hline 15-24 (reference) & 1 if in age range; 0 otherwise & $\mathrm{X}$ & $\mathrm{X}$ & $\mathrm{X}$ & $X$ \\
\hline $25-34$ & 1 if in age range; 0 otherwise & $X$ & $X$ & $\mathrm{X}$ & $X$ \\
\hline $35-44$ & 1 if in age range; 0 otherwise & $\mathrm{X}$ & $\mathrm{X}$ & $\mathrm{X}$ & $\mathrm{X}$ \\
\hline $45-54$ & 1 if in age range; 0 otherwise & $\mathrm{X}$ & $\mathrm{X}$ & $\mathrm{X}$ & $\mathrm{X}$ \\
\hline $55-64$ & 1 if in age range; 0 otherwise & $X$ & $X$ & $\mathrm{X}$ & $X$ \\
\hline 65 and above & 1 if in age range; 0 otherwise & $X$ & $X$ & $X$ & $X$ \\
\hline $\begin{array}{l}\text { Married } \\
\text { Presence of children in household } \\
\text { (at least one): }\end{array}$ & 1 if married; 0 otherwise & $X$ & $\mathrm{X}$ & $\mathrm{X}$ & $X$ \\
\hline Child 0-2 & $\begin{array}{l}1 \text { if child } 0-2 \text { present in household; } 0 \\
\text { otherwise }\end{array}$ & $\mathrm{X}$ & $\mathrm{X}$ & $\mathrm{X}$ & \\
\hline Child 3-5 & $\begin{array}{l}1 \text { if child } 3-5 \text { present in household; } 0 \\
\text { otherwise }\end{array}$ & $X$ & $\mathrm{X}$ & $\mathrm{X}$ & \\
\hline $\begin{array}{l}\text { Child 6-14 } \\
\text { Educational attainment: }\end{array}$ & $\begin{array}{l}1 \text { if child } 6-14 \text { present in household; } 0 \\
\text { otherwise }\end{array}$ & $X$ & $X$ & $X$ & \\
\hline Primary or less (reference) & $\begin{array}{l}1 \text { if completed primary or less; } 0 \\
\text { otherwise }\end{array}$ & $\mathrm{X}$ & $\mathrm{X}$ & $\mathrm{X}$ & $\mathrm{X}$ \\
\hline Lower secondary & $\begin{array}{l}1 \text { if completed lower secondary; } 0 \\
\text { otherwise }\end{array}$ & $X$ & $X$ & $X$ & $X$ \\
\hline Upper secondary & $\begin{array}{l}1 \text { if completed upper secondary; } 0 \\
\text { otherwise }\end{array}$ & $X$ & $X$ & $X$ & $\mathrm{X}$ \\
\hline $\begin{array}{l}\text { Tertiary } \\
\text { Work experience: }\end{array}$ & 1 if completed tertiary; 0 otherwise & $X$ & $X$ & $X$ & $X$ \\
\hline
\end{tabular}

\footnotetext{
${ }^{17}$ In Oct. 2008 for the labor market status transition and the earnings growth analysis, in the current period for the earnings (level) analysis.
} 


\begin{tabular}{|c|c|c|c|c|c|}
\hline Exp & Total work experience (years) & $\mathrm{X}$ & & & $X$ \\
\hline Exp/100 & Total work experience (years)/100 & $\mathrm{X}$ & & & $\mathrm{X}$ \\
\hline \multicolumn{6}{|l|}{ Job characteristics: } \\
\hline No labor contract & 1 if no labor contract; 0 otherwise & $\mathrm{X}$ & & & $\mathrm{X}$ \\
\hline Limited duration & 1 if limited duration; 0 otherwise & $X$ & & & $\mathrm{X}$ \\
\hline Part-time & 1 if part-time; 0 otherwise & $\mathrm{X}$ & & & $\mathrm{X}$ \\
\hline \multicolumn{6}{|l|}{ Sector of employment: } \\
\hline Agriculture (reference) & 1 if Agriculture; 0 otherwise & $\mathrm{X}$ & & & $\mathrm{X}$ \\
\hline Manufacturing-Mining-Electricity & $\begin{array}{l}1 \text { if Manufacturing-Mining-Electricity; } 0 \\
\text { otherwise }\end{array}$ & $X$ & & & $\mathrm{X}$ \\
\hline Construction & 1 if Construction; 0 otherwise & $\mathrm{X}$ & & & $\mathrm{X}$ \\
\hline Trade/Services & 1 if Trade/Services; 0 otherwise & $X$ & & & $\mathrm{X}$ \\
\hline Hotels/Restaurants & 1 if Hotels/Restaurants; 0 otherwise & $\mathrm{X}$ & & & $\mathrm{X}$ \\
\hline Transports & 1 if Transports; 0 otherwise & $X$ & & & $\mathrm{X}$ \\
\hline Financial/Real Estate & 1 if Financial/Real Estate; 0 otherwise & $\mathrm{X}$ & & & $\mathrm{X}$ \\
\hline Public Sector & 1 if Public Sector; 0 otherwise & $\mathrm{X}$ & & & $\mathrm{X}$ \\
\hline Other Sector & 1 if Other Sector; 0 otherwise & $\mathrm{X}$ & & & $\mathrm{X}$ \\
\hline \multicolumn{6}{|l|}{ Firmsize: } \\
\hline Firmsize 1-5 (reference) & 1 if $1-5 ; 0$ otherwise & $\mathrm{X}$ & & & $\mathrm{X}$ \\
\hline Firmsize 6-19 & 1 if $6-19 ; 0$ otherwise & $\mathrm{X}$ & & & $\mathrm{X}$ \\
\hline Firmsize 20-99 & 1 if 20-99; 0 otherwise & $\mathrm{X}$ & & & $\mathrm{X}$ \\
\hline Firmsize $100+$ & 1 if 100 and above ; 0 otherwise & $\mathrm{X}$ & & & $X$ \\
\hline Firmsize not sure: 10 or less & 1 if not sure but 10 or less; 0 otherwise & $\mathrm{X}$ & & & $\mathrm{X}$ \\
\hline Firmsize not sure: 11 or more & 1 if not sure but 11 or more; 0 otherwise & $\mathrm{X}$ & & & $\mathrm{X}$ \\
\hline Earnings/1000 & Net earnings in previous month/1000 & $\mathrm{X}$ & & & \\
\hline Earnings imputed & $\begin{array}{l}1 \text { if "Earnings/1000" was imputed; } 0 \\
\text { otherwise }\end{array}$ & $X$ & & & \\
\hline Unpaid family worker & 1 if unpaid family worker; 0 otherwise & $\mathrm{X}$ & & & \\
\hline HH Income per cap/1000 & $\begin{array}{l}\text { Per capita household income in the } \\
\text { previous month/1000 }\end{array}$ & & $\mathrm{X}$ & $\mathrm{X}$ & \\
\hline $\mathrm{HH}$ income imputed & $\begin{array}{l}1 \text { if "HH Income per cap/1000" was } \\
\text { imputed; } 0 \text { otherwise }\end{array}$ & & $\mathrm{X}$ & $\mathrm{X}$ & \\
\hline UI receipt & $\begin{array}{l}1 \text { if receives unemployment benefit or } \\
\text { assistance; } 0 \text { otherwise }\end{array}$ & & $\mathrm{X}$ & & \\
\hline Urban & 1 if urban; 0 if rural & $\mathrm{X}$ & $\mathrm{X}$ & $\mathrm{X}$ & $\mathrm{X}$ \\
\hline Central Serbia & 1 if Central Serbia; 0 otherwise & $\mathrm{X}$ & $X$ & $\mathrm{X}$ & $\mathrm{X}$ \\
\hline Belgrade (reference) & 1 if Belgrade; 0 otherwise & $\mathrm{X}$ & $X$ & $\mathrm{X}$ & $\mathrm{X}$ \\
\hline Vojvodina & 1 if Vojvodina; 0 otherwise & $\mathrm{X}$ & $\mathrm{X}$ & $\mathrm{X}$ & $X$ \\
\hline
\end{tabular}


APPENDIX B: Descriptive Statistics for Estimation Samples

Table B1. Employment Transitions Analysis: Descriptive Statistics

\begin{tabular}{|c|c|c|c|c|c|c|}
\hline \multirow[b]{2}{*}{ Variable } & \multicolumn{2}{|c|}{ Full sample: } & \multicolumn{2}{|c|}{ Females: } & \multicolumn{2}{|c|}{ Males: } \\
\hline & Mean & Std.Dev. & Mean & Std.Dev. & Mean & Std.Dev. \\
\hline \multicolumn{7}{|l|}{ Dependent variable: } \\
\hline Employed, Oct. 2009 & 0.893 & 0.309 & 0.893 & 0.309 & 0.892 & 0.310 \\
\hline Unemployed, Oct. 2009 & 0.042 & 0.202 & 0.041 & 0.197 & 0.044 & 0.206 \\
\hline Inactive, Oct. 2009 & 0.065 & 0.246 & 0.066 & 0.249 & 0.063 & 0.244 \\
\hline \multicolumn{7}{|l|}{ Explanatory variables: } \\
\hline Female & 0.469 & 0.499 & 1.000 & 0.000 & 0.000 & 0.000 \\
\hline $15-24$ age cohort & 0.093 & 0.290 & 0.072 & 0.259 & 0.111 & 0.314 \\
\hline 25-34 age cohort & 0.201 & 0.401 & 0.188 & 0.391 & 0.212 & 0.409 \\
\hline $35-44$ age cohort & 0.274 & 0.446 & 0.281 & 0.450 & 0.268 & 0.443 \\
\hline 45-54 age cohort & 0.286 & 0.452 & 0.304 & 0.460 & 0.271 & 0.444 \\
\hline 55-64 age cohort & 0.127 & 0.333 & 0.123 & 0.328 & 0.130 & 0.337 \\
\hline 65 and above age cohort & 0.019 & 0.137 & 0.032 & 0.175 & 0.008 & 0.090 \\
\hline Not married & 0.331 & 0.471 & 0.291 & 0.454 & 0.366 & 0.482 \\
\hline Child 0-2 & 0.102 & 0.302 & 0.092 & 0.290 & 0.110 & 0.313 \\
\hline Child 3-5 & 0.096 & 0.295 & 0.092 & 0.289 & 0.100 & 0.300 \\
\hline Child 6-14 & 0.304 & 0.460 & 0.324 & 0.468 & 0.287 & 0.452 \\
\hline Primary or less (reference) & 0.195 & 0.396 & 0.222 & 0.416 & 0.171 & 0.376 \\
\hline Lower secondary & 0.238 & 0.426 & 0.175 & 0.380 & 0.293 & 0.455 \\
\hline Upper secondary & 0.361 & 0.480 & 0.367 & 0.482 & 0.356 & 0.479 \\
\hline Tertiary & 0.207 & 0.405 & 0.236 & 0.425 & 0.181 & 0.385 \\
\hline Work experience & 17.984 & 11.965 & 18.234 & 12.474 & 17.764 & 11.493 \\
\hline $\begin{array}{l}\text { Work experience } \\
\text { squared/100 }\end{array}$ & 4.666 & 5.185 & 4.881 & 5.806 & 4.477 & 4.558 \\
\hline No labor contract & 0.169 & 0.375 & 0.219 & 0.414 & 0.125 & 0.331 \\
\hline Limited duration & 0.219 & 0.414 & 0.260 & 0.439 & 0.183 & 0.387 \\
\hline Part-time & 0.058 & 0.233 & 0.077 & 0.267 & 0.041 & 0.198 \\
\hline Agriculture (reference) & 0.138 & 0.345 & 0.191 & 0.393 & 0.092 & 0.289 \\
\hline Manufacturing-Mining- & & & & & & \\
\hline Electricity & 0.268 & 0.443 & 0.189 & 0.392 & 0.338 & 0.473 \\
\hline Construction & 0.058 & 0.234 & 0.020 & 0.139 & 0.092 & 0.289 \\
\hline Trade/Services & 0.147 & 0.354 & 0.167 & 0.373 & 0.129 & 0.335 \\
\hline Hotels/Restaurants & 0.037 & 0.188 & 0.044 & 0.204 & 0.030 & 0.172 \\
\hline Transports & 0.063 & 0.243 & 0.029 & 0.169 & 0.093 & 0.290 \\
\hline Financial/Real Estate & 0.052 & 0.221 & 0.059 & 0.235 & 0.045 & 0.207 \\
\hline Public Sector & 0.198 & 0.399 & 0.268 & 0.443 & 0.137 & 0.344 \\
\hline Other Sector & 0.040 & 0.195 & 0.033 & 0.180 & 0.045 & 0.207 \\
\hline
\end{tabular}




\begin{tabular}{lcc|cc|cc} 
Firmsize 0-5 (reference) & 0.316 & 0.465 & 0.386 & 0.487 & 0.255 & 0.436 \\
Firmsize 6-19 & 0.265 & 0.441 & 0.257 & 0.437 & 0.273 & 0.445 \\
Firmsize 20-99 & 0.208 & 0.406 & 0.185 & 0.388 & 0.229 & 0.420 \\
Firmsize 100+ & 0.146 & 0.353 & 0.121 & 0.326 & 0.167 & 0.373 \\
Firmsize not sure: 10 or less & 0.020 & 0.139 & 0.015 & 0.120 & 0.024 & 0.153 \\
Firmsize not sure: 11 or & & & & & & \\
more & 0.045 & 0.207 & 0.037 & 0.189 & 0.052 & 0.222 \\
Earnings/10,000 & 2.273 & 1.517 & 2.057 & 1.570 & 2.464 & 1.443 \\
Earnings imputed & 0.070 & 0.255 & 0.065 & 0.246 & 0.075 & 0.263 \\
Unpaid family worker & 0.104 & 0.305 & 0.168 & 0.374 & 0.047 & 0.212 \\
Urban & 0.587 & 0.492 & 0.594 & 0.491 & 0.581 & 0.493 \\
Central Serbia & 0.498 & 0.500 & 0.494 & 0.500 & 0.501 & 0.500 \\
Belgrade (reference) & 0.232 & 0.422 & 0.242 & 0.428 & 0.224 & 0.417 \\
Vojvodina & 0.270 & 0.444 & 0.265 & 0.441 & 0.274 & 0.446 \\
\hline $\mathrm{N}$ & 2,460 & & 1,137 & & 1,323 & \\
\hline
\end{tabular}

Notes: Estimations incorporate sampling weights.

Source: Serbia Labor Force Survey (October 2008 and October 2009 Rounds).

Table B2. Unemployment Transitions Analysis: Descriptive Statistics

\begin{tabular}{|c|c|c|c|c|c|c|}
\hline \multirow[b]{2}{*}{ Variable } & \multicolumn{2}{|c|}{ Full sample: } & \multicolumn{2}{|c|}{ Females: } & \multicolumn{2}{|c|}{ Males: } \\
\hline & Mean & Std.Dev. & Mean & Std.Dev. & Mean & Std.Dev. \\
\hline \multicolumn{7}{|l|}{ Dependent variable: } \\
\hline Employed, Oct. 2009 & 0.092 & 0.289 & 0.078 & 0.268 & 0.105 & 0.307 \\
\hline Unemployed, Oct. 2009 & 0.866 & 0.341 & 0.884 & 0.321 & 0.848 & 0.359 \\
\hline Inactive, Oct. 2009 & 0.042 & 0.202 & 0.039 & 0.193 & 0.046 & 0.210 \\
\hline \multicolumn{7}{|l|}{ Explanatory variables: } \\
\hline Female & 0.495 & 0.500 & 1.000 & 0.000 & 0.000 & 0.000 \\
\hline $15-24$ age cohort & 0.238 & 0.426 & 0.221 & 0.415 & 0.256 & 0.436 \\
\hline $25-34$ age cohort & 0.291 & 0.454 & 0.273 & 0.445 & 0.309 & 0.462 \\
\hline $35-44$ age cohort & 0.178 & 0.383 & 0.225 & 0.418 & 0.132 & 0.339 \\
\hline 45-54 age cohort & 0.230 & 0.421 & 0.261 & 0.439 & 0.199 & 0.400 \\
\hline 55-64 age cohort & 0.062 & 0.241 & 0.020 & 0.141 & 0.103 & 0.304 \\
\hline 65 and above age cohort & 0.000 & 0.000 & 0.000 & 0.000 & 0.000 & 0.000 \\
\hline Not married & 0.486 & 0.500 & 0.390 & 0.488 & 0.582 & 0.493 \\
\hline Child 0-2 & 0.134 & 0.341 & 0.147 & 0.354 & 0.122 & 0.327 \\
\hline Child 3-5 & 0.115 & 0.319 & 0.144 & 0.351 & 0.087 & 0.282 \\
\hline Child 6-14 & 0.226 & 0.418 & 0.271 & 0.444 & 0.181 & 0.385 \\
\hline $\begin{array}{l}\text { Primary or less } \\
\text { (reference) }\end{array}$ & 0.201 & 0.401 & 0.206 & 0.404 & 0.196 & 0.397 \\
\hline Lower secondary & 0.332 & 0.471 & 0.284 & 0.451 & 0.380 & 0.485 \\
\hline
\end{tabular}




\begin{tabular}{lcc|cc|cc} 
Upper secondary & 0.357 & 0.479 & 0.382 & 0.486 & 0.333 & 0.471 \\
Tertiary & 0.110 & 0.312 & 0.128 & 0.334 & 0.092 & 0.289 \\
HH Income per & & & & & & \\
cap/10,000 & 0.796 & 0.513 & 0.832 & 0.537 & 0.761 & 0.487 \\
HH income imputed & 0.068 & 0.251 & 0.067 & 0.250 & 0.068 & 0.252 \\
UI receipt & 0.049 & 0.217 & 0.044 & 0.205 & 0.055 & 0.227 \\
Urban & 0.603 & 0.489 & 0.613 & 0.487 & 0.594 & 0.491 \\
Central Serbia & 0.538 & 0.499 & 0.565 & 0.496 & 0.511 & 0.500 \\
Belgrade (reference) & 0.202 & 0.402 & 0.181 & 0.385 & 0.223 & 0.416 \\
Vojvodina & 0.260 & 0.439 & 0.254 & 0.435 & 0.266 & 0.442 \\
\hline $\mathrm{N}$ & 605 & & \multicolumn{2}{c}{305} & & 300 \\
\hline
\end{tabular}

Notes: Estimations incorporate sampling weights.

Source: Serbia Labor Force Survey (October 2008 and October 2009 Rounds).

Table B3. Inactivity Transitions Analysis: Descriptive Statistics

\begin{tabular}{|c|c|c|c|c|c|c|}
\hline \multirow[b]{2}{*}{ Variable } & \multicolumn{2}{|c|}{ Full sample: } & \multicolumn{2}{|c|}{ Females: } & \multicolumn{2}{|c|}{ Males: } \\
\hline & Mean & Std.Dev. & Mean & Std.Dev. & Mean & Std.Dev. \\
\hline \multicolumn{7}{|l|}{ Dependent variable: } \\
\hline Employed, Oct. 2009 & 0.020 & 0.139 & 0.020 & 0.142 & 0.019 & 0.135 \\
\hline Unemployed, Oct. 2009 & 0.011 & 0.104 & 0.010 & 0.097 & 0.013 & 0.115 \\
\hline Inactive, Oct. 2009 & 0.969 & 0.173 & 0.970 & 0.171 & 0.968 & 0.176 \\
\hline \multicolumn{7}{|l|}{ Explanatory variables: } \\
\hline Female & 0.616 & 0.486 & 1.000 & 0.000 & 0.000 & 0.000 \\
\hline 15-24 age cohort & 0.188 & 0.391 & 0.149 & 0.356 & 0.252 & 0.434 \\
\hline 25-34 age cohort & 0.052 & 0.222 & 0.060 & 0.238 & 0.039 & 0.194 \\
\hline $35-44$ age cohort & 0.042 & 0.200 & 0.057 & 0.231 & 0.018 & 0.132 \\
\hline $45-54$ age cohort & 0.101 & 0.302 & 0.119 & 0.323 & 0.074 & 0.262 \\
\hline 55-64 age cohort & 0.225 & 0.418 & 0.230 & 0.421 & 0.217 & 0.412 \\
\hline 65 and above age cohort & 0.391 & 0.488 & 0.386 & 0.487 & 0.401 & 0.490 \\
\hline Not married & 0.495 & 0.500 & 0.524 & 0.499 & 0.448 & 0.497 \\
\hline Child 0-2 & 0.062 & 0.242 & 0.074 & 0.263 & 0.043 & 0.202 \\
\hline Child 3-5 & 0.054 & 0.225 & 0.065 & 0.247 & 0.035 & 0.185 \\
\hline Child 6-14 & 0.174 & 0.379 & 0.178 & 0.383 & 0.166 & 0.372 \\
\hline $\begin{array}{l}\text { Primary or less } \\
\text { (reference) }\end{array}$ & 0.524 & 0.499 & 0.578 & 0.494 & 0.438 & 0.496 \\
\hline Lower secondary & 0.141 & 0.348 & 0.114 & 0.318 & 0.184 & 0.388 \\
\hline Upper secondary & 0.239 & 0.427 & 0.238 & 0.426 & 0.240 & 0.427 \\
\hline Tertiary & 0.096 & 0.294 & 0.070 & 0.255 & 0.137 & 0.344 \\
\hline $\begin{array}{l}\text { HH Income per } \\
\text { cap } / 10,000\end{array}$ & 1.231 & 0.829 & 1.214 & 0.831 & 1.258 & 0.825 \\
\hline
\end{tabular}




\begin{tabular}{lll|ll|ll} 
HH income imputed & 0.062 & 0.240 & 0.059 & 0.236 & 0.065 & 0.247 \\
Urban & 0.594 & 0.491 & 0.580 & 0.494 & 0.615 & 0.487 \\
Central Serbia & 0.497 & 0.500 & 0.495 & 0.500 & 0.500 & 0.500 \\
Belgrade (reference) & 0.226 & 0.418 & 0.225 & 0.418 & 0.228 & 0.420 \\
Vojvodina & 0.277 & 0.447 & 0.280 & 0.449 & 0.272 & 0.445 \\
\hline $\mathrm{N}$ & 3,641 & \multicolumn{2}{c|}{2,226} & \multicolumn{2}{c}{1,415} \\
\hline
\end{tabular}

Notes: Estimations incorporate sampling weights.

Source: Serbia Labor Force Survey (October 2008 and October 2009 Rounds).

Table B4a. Mincer Earnings (Levels) Analysis-October 2008: Descriptive Statistics

\begin{tabular}{|c|c|c|c|c|c|c|}
\hline \multirow[b]{2}{*}{ Variable } & \multicolumn{2}{|c|}{ Full sample: } & \multicolumn{2}{|c|}{ Females: } & \multicolumn{2}{|c|}{ Males: } \\
\hline & Mean & Std.Dev. & Mean & Std.Dev. & Mean & Std.Dev. \\
\hline \multicolumn{7}{|l|}{ Dependent variable: } \\
\hline Ln (Monthly earnings) & 10.003 & 0.564 & 9.958 & 0.558 & 10.037 & 0.566 \\
\hline Monthly earnings & 25639.0 & 14999.5 & 24515.7 & 13983.0 & 26510.0 & 15687.2 \\
\hline \multicolumn{7}{|l|}{ Explanatory variables: } \\
\hline Female & 0.437 & 0.496 & 1.000 & 0.000 & 0.000 & 0.000 \\
\hline $15-24$ age cohort & 0.073 & 0.261 & 0.061 & 0.239 & 0.083 & 0.276 \\
\hline 25-34 age cohort & 0.238 & 0.426 & 0.233 & 0.423 & 0.242 & 0.428 \\
\hline $35-44$ age cohort & 0.281 & 0.450 & 0.303 & 0.459 & 0.264 & 0.441 \\
\hline 45-54 age cohort & 0.290 & 0.454 & 0.313 & 0.464 & 0.272 & 0.445 \\
\hline 55-64 age cohort & 0.115 & 0.319 & 0.089 & 0.284 & 0.136 & 0.343 \\
\hline 65 and above age cohort & 0.002 & 0.049 & 0.002 & 0.044 & 0.003 & 0.052 \\
\hline Primary or less (reference) & 0.140 & 0.347 & 0.118 & 0.323 & 0.156 & 0.363 \\
\hline Lower secondary & 0.244 & 0.429 & 0.177 & 0.382 & 0.295 & 0.456 \\
\hline Upper secondary & 0.389 & 0.488 & 0.420 & 0.493 & 0.365 & 0.481 \\
\hline Tertiary & 0.228 & 0.419 & 0.285 & 0.452 & 0.183 & 0.387 \\
\hline Work experience & 16.897 & 10.944 & 15.778 & 10.271 & 17.765 & 11.363 \\
\hline Work experience squared/100 & 4.053 & 4.047 & 3.544 & 3.546 & 4.447 & 4.356 \\
\hline No labor contract & 0.081 & 0.272 & 0.059 & 0.235 & 0.098 & 0.297 \\
\hline Limited duration & 0.131 & 0.337 & 0.110 & 0.313 & 0.147 & 0.354 \\
\hline Part-time & 0.027 & 0.162 & 0.022 & 0.146 & 0.031 & 0.174 \\
\hline Agriculture & 0.047 & 0.213 & 0.035 & 0.185 & 0.057 & 0.231 \\
\hline Manufacturing-Mining-Electricity & 0.291 & 0.454 & 0.225 & 0.417 & 0.342 & 0.474 \\
\hline Construction & 0.072 & 0.259 & 0.020 & 0.141 & 0.113 & 0.317 \\
\hline Trade/Services & 0.162 & 0.368 & 0.201 & 0.401 & 0.131 & 0.337 \\
\hline Hotels/Restaurants & 0.034 & 0.181 & 0.040 & 0.196 & 0.029 & 0.167 \\
\hline Transports & 0.067 & 0.249 & 0.039 & 0.194 & 0.088 & 0.283 \\
\hline Financial/Real Estate & 0.057 & 0.231 & 0.071 & 0.257 & 0.045 & 0.208 \\
\hline
\end{tabular}




\begin{tabular}{lll|ll|ll} 
Public Sector & 0.221 & 0.415 & 0.322 & 0.467 & 0.143 & 0.350 \\
Other Sector & 0.049 & 0.216 & 0.045 & 0.208 & 0.052 & 0.222 \\
Firmsize 0-5 & 0.268 & 0.443 & 0.300 & 0.458 & 0.243 & 0.429 \\
Firmsize 6-19 & 0.282 & 0.450 & 0.269 & 0.443 & 0.293 & 0.455 \\
Firmsize 20-99 & 0.235 & 0.424 & 0.236 & 0.425 & 0.235 & 0.424 \\
Firmsize 100+ & 0.156 & 0.363 & 0.146 & 0.353 & 0.164 & 0.371 \\
Firmsize not sure: 10 or less & 0.015 & 0.120 & 0.011 & 0.102 & 0.018 & 0.132 \\
Firmsize not sure: 11 or more & 0.044 & 0.204 & 0.039 & 0.194 & 0.047 & 0.212 \\
Urban & 0.656 & 0.475 & 0.712 & 0.453 & 0.613 & 0.487 \\
Central Serbia & 0.475 & 0.499 & 0.449 & 0.497 & 0.495 & 0.500 \\
Belgrade & 0.232 & 0.422 & 0.257 & 0.437 & 0.213 & 0.409 \\
Vojvodina & 0.293 & 0.455 & 0.294 & 0.456 & 0.292 & 0.455 \\
\hline $\mathrm{N}$ & 4,864 & & 2,080 & & 2,784 & \\
\hline
\end{tabular}

Notes: Estimations incorporate sampling weights.

Source: Serbia Labor Force Survey (October 2008 Round).

Table B4b. Mincer Earnings (Levels) Analysis-October 2009: Descriptive Statistics

\begin{tabular}{lrr|rr|rr}
\hline & \multicolumn{2}{c|}{ Full sample: } & \multicolumn{2}{c|}{ Females: } & \multicolumn{2}{c}{ Males: } \\
\hline Variable & Mean & Std.Dev. & Mean & Std.Dev. & Mean & Std.Dev. \\
& & & & & & \\
Dependent variable: & & & & & & \\
\hline Ln (Monthly earnings) & 10.044 & 0.522 & 10.019 & 0.527 & 10.064 & 0.517 \\
Monthly earnings & 26408.2 & 16178.9 & 25850.4 & 16346.6 & 26862.4 & 16026.8 \\
& & & & & & \\
Explanatory variables: & & & & & & \\
\hline Female & 0.449 & 0.497 & 1.000 & 0.000 & 0.000 & 0.000 \\
15-24 age cohort & 0.058 & 0.234 & 0.050 & 0.218 & 0.065 & 0.246 \\
25-34 age cohort & 0.230 & 0.421 & 0.226 & 0.418 & 0.233 & 0.423 \\
35-44 age cohort & 0.284 & 0.451 & 0.305 & 0.460 & 0.267 & 0.442 \\
45-54 age cohort & 0.300 & 0.458 & 0.323 & 0.468 & 0.281 & 0.450 \\
55-64 age cohort & 0.125 & 0.330 & 0.095 & 0.293 & 0.149 & 0.356 \\
65 and above age cohort & 0.003 & 0.052 & 0.001 & 0.029 & 0.004 & 0.065 \\
Primary or less (reference) & 0.117 & 0.322 & 0.101 & 0.301 & 0.130 & 0.337 \\
Lower secondary & 0.237 & 0.425 & 0.163 & 0.369 & 0.298 & 0.457 \\
Upper secondary & 0.396 & 0.489 & 0.431 & 0.495 & 0.367 & 0.482 \\
Tertiary & 0.249 & 0.433 & 0.305 & 0.461 & 0.204 & 0.403 \\
Work experience & 16.791 & 10.804 & 15.585 & 10.153 & 17.774 & 11.211 \\
Work experience squared/100 & 3.987 & 3.980 & 3.460 & 3.480 & 4.416 & 4.297 \\
No labor contract & 0.050 & 0.219 & 0.037 & 0.189 & 0.061 & 0.239 \\
Limited duration & 0.111 & 0.314 & 0.102 & 0.303 & 0.118 & 0.323 \\
Part-time & 0.023 & 0.149 & 0.026 & 0.159 & 0.020 & 0.141
\end{tabular}




\begin{tabular}{lll|rr|rr} 
Agriculture & 0.031 & 0.174 & 0.017 & 0.127 & 0.043 & 0.203 \\
Manufacturing-Mining-Electricity & 0.275 & 0.447 & 0.195 & 0.396 & 0.341 & 0.474 \\
Construction & 0.055 & 0.228 & 0.017 & 0.130 & 0.086 & 0.280 \\
Trade/Services & 0.155 & 0.361 & 0.187 & 0.390 & 0.128 & 0.334 \\
Hotels/Restaurants & 0.037 & 0.188 & 0.048 & 0.214 & 0.027 & 0.163 \\
Transports & 0.077 & 0.266 & 0.040 & 0.197 & 0.107 & 0.309 \\
Financial/Real Estate & 0.060 & 0.237 & 0.072 & 0.259 & 0.049 & 0.216 \\
Public Sector & 0.257 & 0.437 & 0.371 & 0.483 & 0.165 & 0.371 \\
Other Sector & 0.053 & 0.225 & 0.052 & 0.221 & 0.055 & 0.228 \\
Firmsize 0-5 & 0.257 & 0.437 & 0.287 & 0.452 & 0.232 & 0.422 \\
Firmsize 6-19 & 0.280 & 0.449 & 0.278 & 0.448 & 0.282 & 0.450 \\
Firmsize 20-99 & 0.236 & 0.424 & 0.232 & 0.422 & 0.239 & 0.426 \\
Firmsize 100+ & 0.157 & 0.364 & 0.139 & 0.345 & 0.173 & 0.378 \\
Firmsize not sure: 10 or less & 0.019 & 0.137 & 0.018 & 0.131 & 0.020 & 0.141 \\
Firmsize not sure: 11 or more & 0.051 & 0.220 & 0.047 & 0.212 & 0.054 & 0.225 \\
Urban & 0.665 & 0.472 & 0.722 & 0.448 & 0.619 & 0.486 \\
Central Serbia & 0.465 & 0.499 & 0.434 & 0.496 & 0.490 & 0.500 \\
Belgrade & 0.275 & 0.447 & 0.307 & 0.461 & 0.250 & 0.433 \\
Vojvodina & 0.260 & 0.438 & 0.259 & 0.438 & 0.260 & 0.439 \\
\hline N & 4,607 & & 2,027 & & 2,580 & \\
\hline
\end{tabular}

Notes: Estimations incorporate sampling weights.

Source: Serbia Labor Force Survey (October 2009 Round).

Table B5. Earnings Growth Analysis: Descriptive Statistics

\begin{tabular}{lcc|cc|cc}
\hline & \multicolumn{2}{c|}{ Full sample: } & \multicolumn{2}{c|}{ Females: } & \multicolumn{2}{c}{ Males: } \\
\hline Variable & Mean & Std.Dev. & Mean & Std.Dev. & Mean & Std.Dev. \\
& & & & & & \\
Dependent variable: & & & & & & \\
Earnings growth (percent) & -2.591 & 15.564 & -1.779 & 15.662 & -3.226 & 15.458 \\
& & & & & & \\
Explanatory variables: & & & & & & \\
Female & 0.439 & 0.496 & 1.000 & 0.000 & 0.000 & 0.000 \\
15-24 age cohort & 0.072 & 0.258 & 0.053 & 0.224 & 0.086 & 0.281 \\
25-34 age cohort & 0.216 & 0.412 & 0.202 & 0.401 & 0.228 & 0.419 \\
35-44 age cohort & 0.302 & 0.459 & 0.323 & 0.468 & 0.286 & 0.452 \\
45-54 age cohort & 0.309 & 0.462 & 0.345 & 0.475 & 0.281 & 0.449 \\
55-64 age cohort & 0.099 & 0.299 & 0.076 & 0.265 & 0.118 & 0.322 \\
65 and above age cohort & 0.002 & 0.039 & 0.001 & 0.036 & 0.002 & 0.042 \\
Primary or less (reference) & 0.131 & 0.338 & 0.113 & 0.317 & 0.145 & 0.353 \\
Lower secondary & 0.252 & 0.434 & 0.179 & 0.383 & 0.310 & 0.462
\end{tabular}




\begin{tabular}{lrr|rr|rr} 
Upper secondary & 0.378 & 0.485 & 0.407 & 0.491 & 0.355 & 0.479 \\
Tertiary & 0.239 & 0.426 & 0.301 & 0.459 & 0.190 & 0.392 \\
Work experience & 17.066 & 10.473 & 16.238 & 9.952 & 17.713 & 10.820 \\
Work experience squared/100 & 4.009 & 3.833 & 3.627 & 3.440 & 4.308 & 4.089 \\
No labor contract & 0.048 & 0.214 & 0.037 & 0.189 & 0.056 & 0.231 \\
Limited duration & 0.098 & 0.298 & 0.089 & 0.284 & 0.106 & 0.308 \\
Part-time & 0.021 & 0.144 & 0.021 & 0.142 & 0.022 & 0.146 \\
Agriculture & 0.038 & 0.191 & 0.025 & 0.156 & 0.048 & 0.214 \\
Manufacturing-Mining-Electricity & 0.300 & 0.458 & 0.218 & 0.413 & 0.364 & 0.481 \\
Construction & 0.053 & 0.224 & 0.020 & 0.139 & 0.079 & 0.269 \\
Trade/Services & 0.157 & 0.364 & 0.191 & 0.393 & 0.131 & 0.338 \\
Hotels/Restaurants & 0.041 & 0.199 & 0.054 & 0.225 & 0.032 & 0.175 \\
Transports & 0.070 & 0.256 & 0.036 & 0.187 & 0.097 & 0.296 \\
Financial/Real Estate & 0.050 & 0.218 & 0.065 & 0.247 & 0.038 & 0.192 \\
Public Sector & 0.245 & 0.430 & 0.355 & 0.479 & 0.159 & 0.366 \\
Other Sector & 0.045 & 0.206 & 0.036 & 0.186 & 0.051 & 0.221 \\
Firmsize 0-5 & 0.233 & 0.423 & 0.257 & 0.437 & 0.214 & 0.410 \\
Firmsize 6-19 & 0.289 & 0.453 & 0.295 & 0.456 & 0.284 & 0.451 \\
Firmsize 20-99 & 0.238 & 0.426 & 0.231 & 0.422 & 0.243 & 0.429 \\
Firmsize 100+ & 0.174 & 0.379 & 0.158 & 0.365 & 0.187 & 0.390 \\
Firmsize not sure: 10 or less & 0.016 & 0.127 & 0.014 & 0.116 & 0.018 & 0.135 \\
Firmsize not sure: 11 or more & 0.050 & 0.218 & 0.045 & 0.208 & 0.054 & 0.226 \\
Urban & 0.639 & 0.480 & 0.699 & 0.459 & 0.592 & 0.491 \\
Central Serbia & 0.495 & 0.500 & 0.452 & 0.498 & 0.528 & 0.499 \\
Belgrade & 0.227 & 0.419 & 0.254 & 0.435 & 0.206 & 0.404 \\
Vojvodina & 0.279 & 0.448 & 0.294 & 0.455 & 0.267 & 0.442 \\
\hline N & 1,732 & & 748 & & 984 & \\
\hline & & & & & & \\
& & & & &
\end{tabular}

Notes: Estimations incorporate sampling weights.

Source: Serbia Labor Force Survey (October 2008 and October 2009 Rounds). 


\section{APPENDIX C: Results from Regression Models}

Table C1. Transitions out of Employment, Unemployment and Inactivity: Multinomial Logit Results (Average Marginal Effects)

\begin{tabular}{|c|c|c|c|c|c|c|}
\hline & \multicolumn{2}{|c|}{ Employment Trans: } & \multicolumn{2}{|c|}{ Unemployment Trans: } & \multicolumn{2}{|c|}{ Inactivity Trans: } \\
\hline & Unemp: & Inact: & Emp: & Inact: & Emp: & Unemp: \\
\hline Female & $\begin{array}{l}-0.010 * * * \\
{[0.001]}\end{array}$ & $\begin{array}{l}-0.217 * * * \\
{[0.005]}\end{array}$ & $\begin{array}{l}-0.042 * * * \\
{[0.003]}\end{array}$ & $\begin{array}{l}0.028 * * * \\
{[0.004]}\end{array}$ & $\begin{array}{l}0.067 * * * \\
{[0.001]}\end{array}$ & $\begin{array}{l}-0.044 * * * \\
{[0.001]}\end{array}$ \\
\hline \multicolumn{7}{|l|}{ AGE COHORT: } \\
\hline $25-34$ & $\begin{array}{l}0.006 * * * \\
{[0.001]}\end{array}$ & $\begin{array}{l}-0.073 * * * \\
{[0.001]}\end{array}$ & $\begin{array}{l}0.031 * * * \\
{[0.001]}\end{array}$ & $\begin{array}{l}0.005 * * * \\
{[0.001]}\end{array}$ & $\begin{array}{l}0.037 \text { *** } \\
{[0.001]}\end{array}$ & $\begin{array}{l}0.007 * * * \\
{[0.000]}\end{array}$ \\
\hline $35-44$ & $\begin{array}{l}0.018 * * * \\
{[0.001]}\end{array}$ & $\begin{array}{l}-0.077 * * * \\
{[0.001]}\end{array}$ & $\begin{array}{l}0.037 * * * \\
{[0.002]}\end{array}$ & $\begin{array}{l}0.035 * * * \\
{[0.002]}\end{array}$ & $\begin{array}{l}0.005 * * * \\
{[0.001]}\end{array}$ & $\begin{array}{l}0.002 * * * \\
{[0.000]}\end{array}$ \\
\hline $45-54$ & $\begin{array}{l}0.071 * * * \\
{[0.002]}\end{array}$ & $\begin{array}{l}-0.092 * * * \\
{[0.001]}\end{array}$ & $\begin{array}{l}-0.018 * * * \\
{[0.002]}\end{array}$ & $\begin{array}{l}0.007 * * \\
{[0.003]}\end{array}$ & $\begin{array}{l}0.021 * * * \\
{[0.001]}\end{array}$ & $\begin{array}{l}-0.005 * * * \\
{[0.000]}\end{array}$ \\
\hline $55-64$ & $\begin{array}{l}0.029 * * * \\
{[0.002]}\end{array}$ & $\begin{array}{l}-0.030 * * * \\
{[0.001]}\end{array}$ & $\begin{array}{l}-0.071 * * * \\
{[0.001]}\end{array}$ & $\begin{array}{l}0.278 * * * \\
{[0.010]}\end{array}$ & $\begin{array}{l}0.003 * * * \\
{[0.000]}\end{array}$ & $\begin{array}{l}-0.014 * * * \\
{[0.000]}\end{array}$ \\
\hline 65 plus & $\begin{array}{l}-0.043 * * * \\
{[0.000]}\end{array}$ & $\begin{array}{l}-0.060 * * * \\
{[0.001]}\end{array}$ & & & $\begin{array}{l}-0.014 * * * \\
{[0.000]}\end{array}$ & $\begin{array}{l}-0.027 * * * \\
{[0.000]}\end{array}$ \\
\hline Female X 25-34 & $\begin{array}{l}0.001 \\
{[0.001]}\end{array}$ & $\begin{array}{l}0.187 * * * \\
{[0.005]}\end{array}$ & NA & NA & NA & NA \\
\hline Female X 35-44 & $\begin{array}{l}0.002 \\
{[0.001]}\end{array}$ & $\begin{array}{l}0.141^{* * * *} \\
{[0.005]}\end{array}$ & NA & NA & NA & NA \\
\hline Female X 45-54 & $\begin{array}{l}-0.033 * * * \\
{[0.001]}\end{array}$ & $\begin{array}{l}0.140 * * * \\
{[0.005]}\end{array}$ & NA & NA & NA & NA \\
\hline Female X 55-64 & $\begin{array}{l}-0.045^{* * *} \\
{[0.000]}\end{array}$ & $\begin{array}{l}0.162^{* * * *} \\
{[0.007]}\end{array}$ & NA & NA & NA & NA \\
\hline Female X 65 plus & $\begin{array}{l}-0.040 * * * \\
{[0.000]}\end{array}$ & $\begin{array}{l}0.435 * * * \\
{[0.018]}\end{array}$ & & & NA & NA \\
\hline \multicolumn{7}{|l|}{ MARITAL STATUS: } \\
\hline Single/wid/div & $\begin{array}{l}0.007 * * * \\
{[0.000]}\end{array}$ & $\begin{array}{l}-0.013 * * * \\
{[0.001]}\end{array}$ & $\begin{array}{l}-0.073 * * * \\
{[0.002]}\end{array}$ & $\begin{array}{l}0.122 * * * \\
{[0.002]}\end{array}$ & $\begin{array}{l}0.007 * * * \\
{[0.000]}\end{array}$ & $\begin{array}{l}-0.007 * * * \\
{[0.000]}\end{array}$ \\
\hline Female X Single/wid/div & $\begin{array}{l}0.027 * * * \\
{[0.001]}\end{array}$ & $\begin{array}{l}-0.001 \\
{[0.001]}\end{array}$ & $\begin{array}{l}0.126^{* * * *} \\
{[0.003]}\end{array}$ & $\begin{array}{l}-0.083 * * * \\
{[0.001]}\end{array}$ & $\begin{array}{l}-0.011 * * * \\
{[0.000]}\end{array}$ & $\begin{array}{l}0.043 * * * \\
{[0.001]}\end{array}$ \\
\hline \multicolumn{7}{|l|}{ EDUCATION: } \\
\hline Lower secondary & $\begin{array}{l}0.0003 \\
{[0.001]}\end{array}$ & $\begin{array}{l}-0.041 * * * \\
{[0.001]}\end{array}$ & $\begin{array}{l}0.061 * * * \\
{[0.002]}\end{array}$ & $\begin{array}{l}0.004 * * * \\
{[0.001]}\end{array}$ & $\begin{array}{l}0.002 * * * \\
{[0.000]}\end{array}$ & $\begin{array}{l}-0.006^{* * *} \\
{[0.000]}\end{array}$ \\
\hline Upper secondary & $\begin{array}{l}0.006^{* * * *} \\
{[0.001]}\end{array}$ & $\begin{array}{l}-0.014 * * * \\
{[0.001]}\end{array}$ & $\begin{array}{l}0.075 * * * \\
{[0.002]}\end{array}$ & $\begin{array}{l}-0.021 * * * \\
{[0.001]}\end{array}$ & $\begin{array}{l}0.023 * * * \\
{[0.000]}\end{array}$ & $\begin{array}{l}-0.001 * * * \\
{[0.000]}\end{array}$ \\
\hline Tertiary & $\begin{array}{l}-0.014 * * * \\
{[0.001]}\end{array}$ & $\begin{array}{l}-0.022 * * * \\
{[0.001]}\end{array}$ & $\begin{array}{l}0.261 * * * \\
{[0.004]}\end{array}$ & $\begin{array}{l}-0.033 * * * \\
{[0.001]}\end{array}$ & $\begin{array}{l}0.009 * * * \\
{[0.000]}\end{array}$ & $\begin{array}{l}-0.053 * * * \\
{[0.000]}\end{array}$ \\
\hline Female X Lower secondary & $\begin{array}{l}0.011 * * * \\
{[0.001]}\end{array}$ & $\begin{array}{l}0.147 * * * \\
{[0.002]}\end{array}$ & $\begin{array}{l}-0.049 * * * \\
{[0.002]}\end{array}$ & $\begin{array}{l}0.025 * * * \\
{[0.003]}\end{array}$ & $\begin{array}{l}0.007 * * * \\
{[0.001]}\end{array}$ & $\begin{array}{l}0.006^{* * * *} \\
{[0.001]}\end{array}$ \\
\hline Female X Upper secondary & $0.006 * * *$ & $0.050 * * *$ & $0.030 * * *$ & $0.102 * * *$ & $-0.015^{* * *}$ & $-0.001 * *$ \\
\hline
\end{tabular}


Female X Tertiary

WORK EXPERIENCE:

Exp

Exp squared/100

Female X Exp

Female X Exp squared/100

JOB CHARACTERISTICS:

No labor contract

Limited duration

Part-time

Female X No labor contract

Female X Limited duration

Female X Part-time

PRESENCE OF CHILDREN:

Child 0-2

Child 3-5

Child 6-14

Female X Child 0-2

Female X Child 3-5

Female X Child 6-14

\section{SECTOR:}

Man/Min/Elec

Construction

Trade/Services

\begin{tabular}{ll|ll|ll}
{$[0.001]$} & {$[0.002]$} & {$[0.003]$} & {$[0.004]$} & {$[0.000]$} & {$[0.000]$} \\
$-0.021 * * *$ & $0.060^{* * *}$ & $-0.064 * * *$ & $0.079 * * *$ & $-0.006 * * *$ & $0.895^{* * *}$ \\
{$[0.001]$} & {$[0.002]$} & {$[0.002]$} & {$[0.006]$} & {$[0.000]$} & {$[0.000]$} \\
& & & & & \\
$-0.007 * * *$ & $-0.001 * * *$ & $-0.007 * * *$ & $-0.005 * * *$ & $0.001 * * *$ & $-0.001 * * *$ \\
{$[0.000]$} & {$[0.000]$} & {$[0.000]$} & {$[0.000]$} & {$[0.000]$} & {$[0.000]$} \\
$0.014 * * *$ & $0.006 * * *$ & $0.015 * * *$ & $0.020 * * *$ & $-0.001 * * *$ & $0.002^{* * *}$ \\
{$[0.000]$} & {$[0.000]$} & {$[0.001]$} & {$[0.001]$} & {$[0.000]$} & {$[0.000]$} \\
0 & $0.004 * * *$ & $0.019 * * *$ & $-0.011 * * *$ & $-0.002 * * *$ & $0.001 * * *$ \\
{$[0.000]$} & {$[0.000]$} & {$[0.000]$} & {$[0.000]$} & {$[0.000]$} & {$[0.000]$} \\
$0.001 * * *$ & $-0.009 * * *$ & $-0.176^{* * *}$ & $0.032 * * *$ & $0.002 * * *$ & $-0.001 * * *$ \\
{$[0.000]$} & {$[0.000]$} & {$[0.005]$} & {$[0.001]$} & {$[0.000]$} & {$[0.000]$}
\end{tabular}

$0.017 * * * \quad 0.001$

[0.001] [0.001]

$0.073 * * * \quad 0.033 * * *$

[0.001] [0.001]

$-0.002 * * * \quad 0.013 * * *$

[0.001] [0.001]

$-0.006 * * * 0.096 * * *$

[0.001] [0.003]

$-0.023 * * * \quad-0.017 * * *$

[0.000] [0.001]

$-0.002-0.017 * * *$

[0.001] [0.001]

$0.009 * * * \quad-0.019 * * *$

[0.001] [0.001]

$0.008 * * * \quad-0.029 * * *$

[0.001] [0.001]

$0.022 * * * \quad 0.005 * * *$

[0.001] [0.001]

$-0.019 * * * \quad 0.031 * * *$

[0.001] [0.002]

$-0.006 * * * \quad 0.143 * * *$

[0.001] [0.004]

$0.011 * * * \quad-0.038 * * *$

[0.001]

$0.044 * * *$

[0.001]

$0.057 * * *$

[0.002]

$0.036^{* * * *}$
$-0.042 * * * \quad-0.037 * * *$

[0.001] [0.001]

$-0.006 * * * \quad-0.109 * * *$

[0.001] [0.000]

$-0.025 * * *$

[0.001]

$-0.002$

[0.003]

$-0.085 * * *$

[0.000]

$0.063 * * *$

[0.003]
$-0.008 * * * \quad 0.012 * * *$

[0.000] [0.000]

$-0.004 * * * \quad 0.004 * * *$

[0.000] [0.000]

$-0.007 * * * \quad-0.009 * * *$

[0.000] [0.000]

NA NA

NA NA

NA NA 
Hotels/Restaurants

Transport

Financial/Real Estate

Public Sector

Other Sector

Female X Man/Min/Elec

Female X Construction

Female X Trade/Services

Female X Hotel/Restaurants

Female X Transport

Female X Financial/Real Estate

Female X Public Sector

Female X Other

\section{UNPAID FAMILY WORKER:}

Unpaid family worker

Female X Unpaid family worker

\section{FIRM SIZE:}

Firmsize 6-19

Firmsize 20-99

Firmsize 100+

Firmsize not sure: 10 or less

Firmsize not sure: 11 or more

Female X Firmsize 6-19
[0.001] [0.004]

$-0.018 * * * \quad 0.096 * * *$

[0.001] [0.005]

$-0.022 * * * \quad 0.082 * * *$

[0.001] [0.004]

$0.026 * * * \quad 0.125 * * *$

[0.002] [0.004]

$0.010 * * * \quad 0.019 * * *$

[0.001] [0.002]

$0.010 * * * \quad 0.018 * * *$

[0.001] [0.003]

$-0.030 * * * \quad 0.037 * * *$

[0.001] [0.003]

$-0.044 * * * \quad 0.113 * * *$

[0.000] [0.006]

$-0.053 * * * \quad 0.027 * * *$

[0.001] [0.003]

$-0.028 * * * \quad 0.112 * * *$

[0.001] [0.007]

$-0.028 * * * \quad 0.084 * * *$

[0.001] [0.006]

$-0.036 * * * \quad-0.066 * * *$

[0.001] [0.000]

$-0.043 * * * \quad 0.056 * * *$

[0.001] [0.004]

$-0.033 * * * \quad-0.065 * * *$

[0.001] [0.000]

$-0.047 * * * \quad-0.022 * * *$

[0.000] [0.001]

$0.017 * * * \quad 0.007 * * *$

[0.002] [0.002]

$-0.009 * * * \quad-0.002 * * *$

[0.000] [0.001]

$0.004 * * * \quad 0.021 * * *$

[0.001] [0.001]

$0.005 * * * \quad-0.004 * * *$

[0.001] [0.001]

$-0.028 * * * \quad-0.023 * * *$

[0.001] [0.001]

$-0.009 * * * \quad 0.009 * * *$

[0.001] [0.001]

$0.008^{* * *} \quad 0.016^{* * *}$ 
Female X Firmsize 20-99

Female X Firmsize 100+

Female X Firmsize not sure: 10 or less

Female X Firmsize not sure: 11 or more

SALARY:

Earnings/10, 000

Female X Earnings/10, 000

Earnings imputed, dummy

Female X Earnings imputed, dummy

HH INCOME (PER CAP):

HH Income per cap/10,000

Female X HH Income per cap/10,000

Income imputed, dummy

Female X Income imputed, dummy

\section{UI RECEIPT:}

UI receipt

Female X UI receipt

\section{GEOGRAPHIC LOCATION:}

Urban

Central Serbia

Female X Vojvodina

Female X Urban

Female X Central Serbia

Vojvodina

$\begin{array}{ll}{[0.001]} & {[0.001]} \\ 0.023 * * * & -0.021 * * * \\ {[0.001]} & {[0.001]} \\ -0.019 * * * & -0.010^{* * *} \\ {[0.001]} & {[0.001]} \\ -0.043 * * * & 0.358^{* * *} \\ {[0.000]} & {[0.007]} \\ -0.043 * * * & -0.019 * * * \\ {[0.000]} & {[0.001]} \\ & \\ -0.014 * * * & 0 \\ {[0.000]} & {[0.000]} \\ 0.009 * * * & -0.012 * * * \\ {[0.000]} & {[0.000]} \\ 0.014 * * * & 0.001 \\ {[0.001]} & {[0.001]} \\ 0.024 * * * & -0.039 * * * \\ {[0.002]} & {[0.001]}\end{array}$

$-0.009 * * * \quad-0.015 * * *$

[0.001] [0.001]

NA NA

$0.036 * * * \quad 0.049 * * *$

[0.002] [0.002]

$0.213 * * * \quad 0.006 * * *$

[0.006] [0.002]

$0.276 * * * \quad-0.060 * * *$

[0.004] [0.000]

$-0.091 * * * \quad 0.926 * * *$

[0.000] [0.001]

$0.015^{* * *} \quad 0.020 * * *$

[0.000] [0.001]

$-0.014 * * * \quad-0.005 * * *$

[0.000] [0.001]

$-0.008^{* * *}-0.026 * * *$

[0.001]

[0.001]

$0.021 * * * \quad-0.014 * * *$

[0.001] [0.001]

$0.065^{* * *} \quad 0.016^{* * *}$

[0.002]

[0.001]

$0.056^{* * *} \quad 0.052^{* * *}$
$-0.002 * * * \quad-0.003 * * *$

[0.000] [0.000]

$0.002 * * * \quad 0.003 * * *$

[0.000] [0.000]

$0.015 * * * \quad-0.004 * * *$

[0.001] [0.000]

$-0.021 * * * \quad 0.003 * * *$

[0.000] [0.001]

$-0.005 * * * \quad 0.002 * * *$

[0.000] [0.000]

NA NA

NA NA

$-0.013 * * * \quad-0.009 * * *$

[0.000] [0.000]

$-0.026^{* * *} \quad 0.001 * * *$

[0.000] [0.000]

$-0.022 * * * \quad 0.003 * * *$ 


\begin{tabular}{lcc|cc|cc} 
& {$[0.002]$} & {$[0.001]$} & {$[0.001]$} & {$[0.001]$} & {$[0.000]$} & {$[0.000]$} \\
\hline $\mathrm{N}$ & & 2,460 & \multicolumn{2}{c|}{605} & 3,641 \\
\hline
\end{tabular}

Notes: Estimations employ robust Huber-White (Huber, 1967; White, 1980) standard errors and incorporate sampling weights. Reference groups are: "Primary or less" (education completed); "Agriculture" (industry); "Firmsize 1-5" (firm size); "Belgrade" (region). Additional controls include dummy variables for imputed earnings, imputed household income, and unpaid family workers. "NA": not available (due to convergence problems when including variable(s)). *: statistically significant at 10 percent; **: statistically significant at 5 percent; ***: statistically significant at 1 percent.

Source: Serbia Labor Force Survey (October 2008 and October 2009 Rounds).

Table C2. Mincer Earnings Equations: OLS Results

\begin{tabular}{|c|c|c|c|c|}
\hline & \multicolumn{2}{|c|}{ Oct. 2008: } & \multicolumn{2}{|c|}{ Oct. 2009: } \\
\hline & $\begin{array}{l}\text { Only female } \\
\text { dummy } \\
+ \text { control } \\
\text { variables: }\end{array}$ & $\begin{array}{l}\text { Fully } \\
\text { interacted } \\
\text { model: }\end{array}$ & $\begin{array}{l}\text { Only female } \\
\text { dummy } \\
+ \text { control } \\
\text { variables: }\end{array}$ & $\begin{array}{l}\text { Fully } \\
\text { interacted } \\
\text { model: }\end{array}$ \\
\hline Female & $\begin{array}{l}-0.175^{* * *} \\
{[0.001]}\end{array}$ & $\begin{array}{l}-0.064 * * * \\
{[0.006]}\end{array}$ & $\begin{array}{l}-0.133 * * * \\
{[0.001]}\end{array}$ & $\begin{array}{l}-0.270 * * * \\
{[0.006]}\end{array}$ \\
\hline AGE COHORT: & & & & \\
\hline $25-34$ & $\begin{array}{l}0.069 * * * \\
{[0.002]}\end{array}$ & $\begin{array}{l}0.137 * * * \\
{[0.002]}\end{array}$ & $\begin{array}{l}-0.007 * * * \\
{[0.001]}\end{array}$ & $\begin{array}{l}0.034 * * * \\
{[0.002]}\end{array}$ \\
\hline $35-44$ & $\begin{array}{l}0.045^{* * *} * \\
{[0.002]}\end{array}$ & $\begin{array}{l}0.114 * * * \\
{[0.003]}\end{array}$ & $\begin{array}{l}-0.013 * * * \\
{[0.002]}\end{array}$ & $\begin{array}{l}0.020 * * * \\
{[0.003]}\end{array}$ \\
\hline $45-54$ & $\begin{array}{l}0.030 * * * \\
{[0.002]}\end{array}$ & $\begin{array}{l}0.089 * * * \\
{[0.003]}\end{array}$ & $\begin{array}{l}-0.056 * * * \\
{[0.002]}\end{array}$ & $\begin{array}{l}-0.046 * * * \\
{[0.003]}\end{array}$ \\
\hline $55-64$ & $\begin{array}{l}0.067 * * * \\
{[0.002]}\end{array}$ & $\begin{array}{l}0.129 * * * \\
{[0.004]}\end{array}$ & $\begin{array}{l}-0.116 * * * \\
{[0.002]}\end{array}$ & $\begin{array}{l}-0.177 * * * \\
{[0.004]}\end{array}$ \\
\hline 65 plus & $\begin{array}{l}0.376 * * * \\
{[0.007]}\end{array}$ & $\begin{array}{l}0.518 * * * \\
{[0.008]}\end{array}$ & $\begin{array}{l}-0.030 * * * \\
{[0.010]}\end{array}$ & $\begin{array}{l}-0.163 * * * \\
{[0.011]}\end{array}$ \\
\hline Female X 25-34 & & $\begin{array}{l}-0.156^{* * *} \\
{[0.003]}\end{array}$ & & $\begin{array}{l}-0.084 * * * \\
{[0.003]}\end{array}$ \\
\hline Female X 35-44 & & $\begin{array}{l}-0.135^{* * *} * \\
{[0.003]}\end{array}$ & & $\begin{array}{l}-0.037 * * * \\
{[0.003]}\end{array}$ \\
\hline Female X 45-54 & & $\begin{array}{l}-0.102 * * * \\
{[0.004]}\end{array}$ & & $\begin{array}{l}0.003 \\
{[0.004]}\end{array}$ \\
\hline Female X 55-64 & & $\begin{array}{l}-0.088 * * * \\
{[0.005]}\end{array}$ & & $\begin{array}{l}0.165 * * * \\
{[0.005]}\end{array}$ \\
\hline Female X 65 plus & & $\begin{array}{l}-0.222 * * * \\
{[0.015]}\end{array}$ & & $\begin{array}{l}0.698 * * * \\
{[0.012]}\end{array}$ \\
\hline EDUCATION: & & & & \\
\hline Lower secondary & $\begin{array}{l}0.144 * * * \\
{[0.001]}\end{array}$ & $\begin{array}{l}0.142 * * * \\
{[0.002]}\end{array}$ & $\begin{array}{l}0.092 * * * \\
{[0.001]}\end{array}$ & $\begin{array}{l}0.076^{* * * *} \\
{[0.002]}\end{array}$ \\
\hline Upper secondary & $\begin{array}{l}0.270 * * * \\
{[0.001]}\end{array}$ & $\begin{array}{l}0.236 * * * \\
{[0.002]}\end{array}$ & $\begin{array}{l}0.228 * * * \\
{[0.001]}\end{array}$ & $\begin{array}{l}0.213 * * * \\
{[0.002]}\end{array}$ \\
\hline Tertiary & $\begin{array}{l}0.697 * * * \\
{[0.001]}\end{array}$ & $\begin{array}{l}0.649 * * * \\
{[0.002]}\end{array}$ & $\begin{array}{l}0.645 * * * \\
{[0.001]}\end{array}$ & $\begin{array}{l}0.583 * * * \\
{[0.002]}\end{array}$ \\
\hline Female X Lower secondary & & $\begin{array}{l}-0.006 * * * \\
{[0.002]}\end{array}$ & & $\begin{array}{l}0.029 * * * \\
{[0.002]}\end{array}$ \\
\hline Female X Upper secondary & & $\begin{array}{l}0.088 * * * \\
{[0.002]}\end{array}$ & & $\begin{array}{l}0.045^{* * * *} \\
{[0.002]}\end{array}$ \\
\hline
\end{tabular}


Female X Tertiary

WORK EXPERIENCE:

Experience

Experience squared/100

Female X Experience

Female X Exp squared/100

JOB CHARACTERISTICS:

No labor contract

Limited duration

Part-time

Female X No labor contract

Female X Limited duration

Female X Part-time

SECTOR:

Man/Min/Elec

Construction

Trade/Services

Hotels/Restaurants

Transport

Financial/Real Estate

Public Sector

Other Sector

Female X Man/Min/Elec

Female X Construction

Female X Trade/Services

Female X Hotel/Restaurants

Female X Transport

Female X Financial/Real Estate

Female X Public Sector

\begin{tabular}{|c|c|c|c|}
\hline & $\begin{array}{l}0.117 * * * \\
{[0.003]}\end{array}$ & & $\begin{array}{l}0.137 * * * \\
{[0.002]}\end{array}$ \\
\hline $\begin{array}{l}0.014 * * * \\
{[0.000]} \\
-0.027 * * * \\
{[0.000]}\end{array}$ & $\begin{array}{l}0.012 * * * \\
{[0.000]} \\
-0.025 * * * \\
{[0.001]} \\
0 \\
{[0.000]} \\
-0.001 \\
{[0.001]}\end{array}$ & $\begin{array}{l}0.007 * * * \\
{[0.000]} \\
-0.001 * * * \\
{[0.000]}\end{array}$ & $\begin{array}{l}0.003 * * * \\
{[0.000]} \\
0.012 * * * \\
{[0.001]} \\
0.005 * * * \\
{[0.000]} \\
-0.022 * * * \\
{[0.001]}\end{array}$ \\
\hline $\begin{array}{l}-0.203 * * * \\
{[0.002]} \\
-0.104 * * * \\
{[0.001]} \\
-0.595 * * * \\
{[0.004]}\end{array}$ & $\begin{array}{l}-0.180^{* * *} \\
{[0.002]} \\
-0.124 * * * \\
{[0.002]} \\
-0.600^{* * *} \\
{[0.005]} \\
-0.078^{* * *} \\
{[0.003]} \\
0.039 * * * \\
{[0.002]} \\
0.033 * * * \\
{[0.008]}\end{array}$ & $\begin{array}{l}-0.135 * * * \\
{[0.002]} \\
-0.117 * * * \\
{[0.001]} \\
-0.360 * * * \\
{[0.002]}\end{array}$ & $\begin{array}{l}-0.102 * * * \\
{[0.003]} \\
-0.134 * * * \\
{[0.002]} \\
-0.287 * * * \\
{[0.004]} \\
-0.083 * * * \\
{[0.004]} \\
0.041^{* * *} \\
{[0.002]} \\
-0.133 * * * \\
{[0.005]}\end{array}$ \\
\hline $\begin{array}{l}0.235^{* * * *} \\
{[0.002]} \\
0.376^{* * *} \\
{[0.002]} \\
0.141^{* * * *} \\
{[0.002]} \\
0.131^{* * * *} \\
{[0.003]} \\
0.299^{* * * *} \\
{[0.002]} \\
0.323^{* * *} \\
{[0.003]} \\
0.358^{* * *} \\
{[0.002]} \\
0.272^{* * * *} \\
{[0.003]}\end{array}$ & $\begin{array}{l}0.295 * * * \\
{[0.003]} \\
0.417 * * * \\
{[0.003]} \\
0.180 * * * \\
{[0.003]} \\
0.134 * * * \\
{[0.004]} \\
0.351^{* * *} \\
{[0.003]} \\
0.272^{* * *} \\
{[0.004]} \\
0.356^{* * *} \\
{[0.003]} \\
0.347 * * * \\
{[0.004]} \\
-0.188^{* * *} \\
{[0.004]} \\
-0.247 * * * \\
{[0.006]} \\
-0.120^{* * *} \\
{[0.005]} \\
-0.041^{* * *} \\
{[0.005]} \\
-0.189^{*} * * * \\
{[0.005]} \\
0.024 * * * \\
{[0.005]} \\
-0.068^{* * * *} \\
{[0.004]}\end{array}$ & $\begin{array}{l}0.111 * * * \\
{[0.002]} \\
0.218^{* * *} \\
{[0.002]} \\
0.047 * * * \\
{[0.002]} \\
0.066 * * * \\
{[0.003]} \\
0.169 * * * \\
{[0.002]} \\
0.237 * * * \\
{[0.003]} \\
0.219 * * * \\
{[0.002]} \\
0.085^{* * *} \\
{[0.002]}\end{array}$ & $\begin{array}{l}0.131 * * * \\
{[0.002]} \\
0.203 * * * \\
{[0.003]} \\
0.057 * * * \\
{[0.003]} \\
0.014 * * * \\
{[0.004]} \\
0.161 * * * \\
{[0.003]} \\
0.125 * * * \\
{[0.003]} \\
0.226 * * * \\
{[0.003]} \\
0.060^{* * *} \\
{[0.003]} \\
-0.021 * * * \\
{[0.005]} \\
0.075 * * * \\
{[0.006]} \\
0.032^{* * *} \\
{[0.005]} \\
0.141 * * * \\
{[0.006]} \\
0.070^{* * *} \\
{[0.005]} \\
0.244 * * * \\
{[0.006]} \\
0.029 * * * \\
{[0.005]}\end{array}$ \\
\hline
\end{tabular}




\begin{tabular}{|c|c|c|c|c|}
\hline Female X Other & & $\begin{array}{l}-0.201 * * * \\
{[0.005]}\end{array}$ & & $\begin{array}{l}0.102 * * * \\
{[0.005]}\end{array}$ \\
\hline FIRM SIZE: & & & & \\
\hline Firmsize 6-19 & $\begin{array}{l}0.081 * * * \\
{[0.001]}\end{array}$ & $\begin{array}{l}0.079 * * * \\
{[0.001]}\end{array}$ & $\begin{array}{l}0.083 * * * \\
{[0.001]}\end{array}$ & $\begin{array}{l}0.071 * * * \\
{[0.001]}\end{array}$ \\
\hline Firmsize 20-99 & $\begin{array}{l}0.094 * * * \\
{[0.001]}\end{array}$ & $\begin{array}{l}0.100 * * * \\
{[0.001]}\end{array}$ & $\begin{array}{l}0.127 * * * \\
{[0.001]}\end{array}$ & $\begin{array}{l}0.147 * * * \\
{[0.001]}\end{array}$ \\
\hline Firmsize $100+$ & $\begin{array}{l}0.135 * * * \\
{[0.001]}\end{array}$ & $\begin{array}{l}0.136 * * * \\
{[0.002]}\end{array}$ & $\begin{array}{l}0.130 * * * \\
{[0.001]}\end{array}$ & $\begin{array}{l}0.130 * * * \\
{[0.001]}\end{array}$ \\
\hline Firmsize not sure: 10 or less & $\begin{array}{l}0.047 * * * \\
{[0.003]}\end{array}$ & $\begin{array}{l}-0.002 \\
{[0.004]}\end{array}$ & $\begin{array}{l}0.003 \\
{[0.003]}\end{array}$ & $\begin{array}{l}-0.115 * * * \\
{[0.004]}\end{array}$ \\
\hline Firmsize not sure: 11 or more & $\begin{array}{l}0.135^{* * * *} \\
{[0.002]}\end{array}$ & $\begin{array}{l}0.175 * * * \\
{[0.002]}\end{array}$ & $\begin{array}{l}0.139 * * * \\
{[0.001]}\end{array}$ & $\begin{array}{l}0.154 * * * \\
{[0.002]}\end{array}$ \\
\hline Female X Firmsize 6-19 & & $\begin{array}{l}0.002 \\
{[0.002]}\end{array}$ & & $\begin{array}{l}0.020 * * * \\
{[0.002]}\end{array}$ \\
\hline Female X Firmsize 20-99 & & $\begin{array}{l}-0.018 \text { *** } \\
{[0.002]}\end{array}$ & & $\begin{array}{l}-0.052 * * * \\
{[0.002]}\end{array}$ \\
\hline Female X Firmsize 100+ & & $\begin{array}{l}0.002 \\
{[0.002]}\end{array}$ & & $\begin{array}{l}0.002 \\
{[0.002]}\end{array}$ \\
\hline Female X Firmsize not sure: 10 or less & & $\begin{array}{l}0.121 * * * \\
{[0.006]}\end{array}$ & & $\begin{array}{l}0.269 * * * \\
{[0.005]}\end{array}$ \\
\hline Female X Firmsize not sure: 11 or more & & $\begin{array}{l}-0.095^{* * *} \\
{[0.003]}\end{array}$ & & $\begin{array}{l}-0.043 * * * \\
{[0.003]}\end{array}$ \\
\hline GEOGRAPHIC LOCATION: & & & & \\
\hline Urban & $\begin{array}{l}0.047 * * * \\
{[0.001]}\end{array}$ & $\begin{array}{l}0.016^{* * * *} \\
{[0.001]}\end{array}$ & $\begin{array}{l}0.071 * * * \\
{[0.001]}\end{array}$ & $\begin{array}{l}0.053^{* * *} \\
{[0.001]}\end{array}$ \\
\hline Central Serbia & $\begin{array}{l}-0.239 * * * \\
{[0.001]}\end{array}$ & $\begin{array}{l}-0.246^{* * * *} \\
{[0.001]}\end{array}$ & $\begin{array}{l}-0.253 * * * \\
{[0.001]}\end{array}$ & $\begin{array}{l}-0.285^{* * *} \\
{[0.001]}\end{array}$ \\
\hline Vojvodina & $\begin{array}{l}-0.159 * * * \\
{[0.001]}\end{array}$ & $\begin{array}{l}-0.171 \text { *** } \\
{[0.001]}\end{array}$ & $\begin{array}{l}-0.175 * * * \\
{[0.001]}\end{array}$ & $\begin{array}{l}-0.179 * * * \\
{[0.001]}\end{array}$ \\
\hline Female X Urban & & $\begin{array}{l}0.078 * * * \\
{[0.001]}\end{array}$ & & $\begin{array}{l}0.040 * * * \\
{[0.001]}\end{array}$ \\
\hline Female X Central Serbia & & $\begin{array}{l}0.008 * * * \\
{[0.002]}\end{array}$ & & $\begin{array}{l}0.065 * * * \\
{[0.002]}\end{array}$ \\
\hline Female X Vojvodina & & $\begin{array}{l}0.027 * * * \\
{[0.002]}\end{array}$ & & $\begin{array}{l}0.008 * * * \\
{[0.002]}\end{array}$ \\
\hline Constant & $\begin{array}{l}9.459 * * * \\
{[0.003]}\end{array}$ & $\begin{array}{l}9.428 * * * \\
{[0.004]}\end{array}$ & $\begin{array}{l}9.681 * * * \\
{[0.003]}\end{array}$ & $\begin{array}{l}9.721 * * * \\
{[0.003]}\end{array}$ \\
\hline $\begin{array}{l}\mathrm{R}^{2} \\
\mathrm{~N}\end{array}$ & 0.48 & $\begin{array}{l}0.49 \\
64 \\
\end{array}$ & 0.43 & $\begin{array}{l}0.44 \\
07\end{array}$ \\
\hline
\end{tabular}

Notes: Estimations employ robust Huber-White (Huber, 1967; White, 1980) standard errors and incorporate sampling weights.

Reference groups are: "Primary or less" (education completed); "Agriculture" (sector); "1-5" (Firm size); and "Belgrade" (region). *: statistically significant at 10 percent; **: statistically significant at 5 percent; ***: statistically significant at 1 percent.

Source: Serbia Labor Force Survey (October 2008 and October 2009 Rounds).

Table C3. Earnings Growth: OLS Results

\begin{tabular}{llll}
\hline $\begin{array}{l}\text { Female } \\
\text { dummy }+\end{array}$ & $\begin{array}{l}\text { Adding (non- } \\
\text { interacted) }\end{array}$ & $\begin{array}{l}\text { Fully } \\
\text { interacted }\end{array}$ \\
\hline
\end{tabular}




\begin{tabular}{|c|c|c|c|}
\hline & $\begin{array}{l}\text { constant } \\
\text { term: }\end{array}$ & $\begin{array}{l}\text { explanatory } \\
\text { variables: }\end{array}$ & model: \\
\hline Female & $\begin{array}{l}1.447 * * * \\
{[0.025]}\end{array}$ & $\begin{array}{l}0.746 * * * \\
{[0.027]}\end{array}$ & $\begin{array}{l}-23.980 * * * \\
{[0.228]}\end{array}$ \\
\hline \multicolumn{4}{|l|}{ AGE COHORT: } \\
\hline $25-34$ & & $\begin{array}{l}0.755^{* * *} * \\
{[0.065]}\end{array}$ & $\begin{array}{l}0.306 * * * \\
{[0.083]}\end{array}$ \\
\hline $35-44$ & & $\begin{array}{l}1.268 * * * \\
{[0.076]}\end{array}$ & $\begin{array}{l}1.010 * * * \\
{[0.109]}\end{array}$ \\
\hline $45-54$ & & $\begin{array}{l}3.233 * * * \\
{[0.085]}\end{array}$ & $\begin{array}{l}3.325 * * * \\
{[0.126]}\end{array}$ \\
\hline $55-64$ & & $\begin{array}{l}0.698 * * * \\
{[0.096]}\end{array}$ & $\begin{array}{l}0.647 * * * \\
{[0.143]}\end{array}$ \\
\hline Female X 25-34 & & & $\begin{array}{l}2.214 * * * \\
{[0.135]}\end{array}$ \\
\hline Female X 35-44 & & & $\begin{array}{l}2.195 * * * \\
{[0.155]}\end{array}$ \\
\hline Female X 45-54 & & & $\begin{array}{l}1.436 * * * \\
{[0.175]}\end{array}$ \\
\hline Female X 55-64 & & & $\begin{array}{l}2.300 * * * \\
{[0.196]}\end{array}$ \\
\hline EDUCATION: & & & \\
\hline Lower secondary & & $\begin{array}{l}2.282 * * * \\
{[0.048]}\end{array}$ & $\begin{array}{l}0.309 * * * \\
{[0.057]}\end{array}$ \\
\hline Upper secondary & & $\begin{array}{l}0.736 * * * \\
{[0.046]}\end{array}$ & $\begin{array}{l}-0.036 \\
{[0.058]}\end{array}$ \\
\hline Tertiary & & $\begin{array}{l}0.853 * * * \\
{[0.049]}\end{array}$ & $\begin{array}{l}0.517 * * * \\
{[0.066]}\end{array}$ \\
\hline Female X Lower secondary & & & $\begin{array}{l}5.264 * * * \\
{[0.104]}\end{array}$ \\
\hline Female X Upper secondary & & & $\begin{array}{l}1.322 * * * \\
{[0.098]}\end{array}$ \\
\hline Female X Tertiary & & & $\begin{array}{l}0.444 * * * \\
{[0.103]}\end{array}$ \\
\hline WORK EXPERIENCE: & & & \\
\hline Experience & & $\begin{array}{l}-0.120 * * * \\
{[0.007]}\end{array}$ & $\begin{array}{l}-0.136^{* * * *} \\
{[0.009]}\end{array}$ \\
\hline Experience squared/100 & & $\begin{array}{l}-0.202 * * * \\
{[0.017]}\end{array}$ & $\begin{array}{l}-0.214 * * * \\
{[0.021]}\end{array}$ \\
\hline Female X Experience & & & $\begin{array}{l}-0.185^{* * *} \\
{[0.014]}\end{array}$ \\
\hline Female X Experience squared/100 & & & $\begin{array}{l}0.547 * * * \\
{[0.034]}\end{array}$ \\
\hline
\end{tabular}




\section{JOB CHARACTERISTICS:}

No labor contract

$\begin{array}{ll}-1.692 * * * & -2.020 * * * \\ {[0.085]} & {[0.095]} \\ 3.166 * * * & 2.978 * * * \\ {[0.054]} & {[0.068]} \\ 4.084 * * * & 8.433 * * * \\ {[0.128]} & {[0.150]} \\ & 3.568 * * * \\ & {[0.197]} \\ & 1.314 * * * \\ & {[0.111]} \\ & -10.385 * * * \\ & {[0.243]}\end{array}$

\section{SECTOR:}

Man/Min/Elec

$3.336 * * * \quad-1.880 * * *$

[0.088] [0.095]

Construction

0.016

$-5.842 * * *$

Trade/Services

[0.099]

[0.111]

Hotel/Restaurants

$5.003 * * *$

$-0.894 * * *$

[0.095]

[0.107]

$2.230 * * *$

$-5.177 * * *$

[0.103]

[0.128]

Transport

$5.876^{* * * *}$

0.006

Financial/Real Estate

[0.099]

[0.109]

$6.115 * * *$

$-2.330 * * *$

[0.107]

[0.137]

Public Sector

$4.875 * * *$

$-0.630 * * *$

[0.089]

[0.100]

Other Sector

$5.947 * * *$

$-1.157 * * *$

[0.099]

[0.111]

Female X Man/Min/Elec

$18.926 * * *$

[0.190]

Female X Construction

$22.467 * * *$

[0.208]

Female X Trade/Services

$20.661 * * *$

[0.202]

Female X Hotels/Restaurants

$22.938 * * *$

[0.215]

Female X Transport

$21.241 * * *$

[0.226]

Female X Financial/Real Estate

$25.459 * * *$

[0.228]

$19.750 * * *$

[0.191] 


\section{FIRM SIZE:}

Firmsize 6-19

$\begin{array}{ll}-0.117 * * * & -1.455^{* * *} \\ {[0.037]} & {[0.048]} \\ 1.197 * * * & -1.106 * * * \\ {[0.038]} & {[0.049]} \\ 0.408 * * * & -1.312 * * * \\ {[0.040]} & {[0.052]} \\ 1.913 * * * & 0.614 * * * \\ {[0.089]} & {[0.095]} \\ 0.276 * * * & 0.245 * * * \\ {[0.064]} & {[0.076]}\end{array}$

Female X Firmsize 6-19

Female X Firmsize 20-99

Female X Firmsize 100+

[0.077]

Female X Firmsize not sure: 10 or less

Female X Firmsize not sure: 11 or more

Urban

Central Serbia

Vojvodina

Female X Urban

Female X Central Serbia

Female X Vojvodina

Constant

\begin{tabular}{llll}
\hline $\mathrm{R}^{2}$ & 0.002 & 0.035 & 0.060 \\
$\mathrm{~N}$ & 1,732 & 1,732 & 1,732 \\
\hline
\end{tabular}

Notes: Estimations employ robust Huber-White (Huber, 1967; White, 1980) standard errors and incorporate sampling weights. Reference groups are: "Primary or less" (education completed); "Agriculture" (sector); "1-5" (Firm size); and "Belgrade" (region). *: statistically significant at 10 percent; **: statistically significant at 5 percent; ***: statistically significant at 1 percent.

Source: Serbia Labor Force Survey (October 2008 and October 2009 Rounds). 
